Accepted refereed manuscript of:

Paikaray S, Schröder C \& Peiffer S (2017) Schwertmannite stability in anoxic Fe(II)-rich aqueous solution, Geochimica et Cosmochimica Acta, 217, pp. 292-305.

DOI: $\underline{10.1016 / j . g c a .2017 .08 .026}$

(C) 2017, Elsevier. Licensed under the Creative Commons Attribution-NonCommercialNoDerivatives 4.0 International http://creativecommons.org/licenses/by-nc-nd/4.0/ 


\title{
Schwertmannite stability in anoxic Fe(II)-rich aqueous solution
}

\author{
Susanta Paikaray $^{1 *}$, Christian Schröder $^{2}$ and Stefan Peiffer ${ }^{1}$ \\ ${ }^{1}$ Department of Hydrology, BayCEER, University of Bayreuth, D-95440, Bayreuth, \\ Germany \\ ${ }^{2}$ Biological and Environmental Sciences, Faculty of Natural Sciences, University of \\ Stirling, Stirling FK9 4LA, Scotland, UK
}

\section{Abstract}

Schwertmannite (SHM) is a powerful scavenger for As(III) leading to As(III)-enriched precipitates around acid mine drainage environments that may become exposed to aqueous $\mathrm{Fe}(\mathrm{II})$. In this study we have investigated the stability of pure SHM and SHM containing 0.92 wt \% As(III) under Fe(II) $)_{\text {qq }}$-rich (0.4-1.0 mM) anoxic conditions using XRD, SEM, Mössbauer and FTIR spectroscopic techniques. Schwertmannite transformation proceeded through an alkalinity-driven pathway releasing sulfate and a $\mathrm{Fe}(\mathrm{II})$-catalyzed pathway that generated lepidocrocite and goethite at $\mathrm{pH} 6$ and 6.9 in the presence of $1 \mathrm{mM} \mathrm{Fe}(\mathrm{II})_{\mathrm{aq}}$. Lepidocrocite was found to be needle shaped if the SHM contained As(III) and platy for pure SHM. Goethite had a poor degree of crystallinity in As(III) containing SHM. Pre-adsorption of As(III) inhibited the extent of SHM transformation. Fe(II) sorption onto SHM was pH dependent and reflected a sorption edge with complete consumption at $\mathrm{pH} 6.9$, while only $\sim 20 \%$ were adsorbed at $\mathrm{pH}$ 5. Surface coverage with Fe(II) appears to be the key parameter controlling extent and products of the transformation process. As(III) concentrations in solution are controlled by two mechanisms: 1) exchange of As(III) for sulfate upon alkalinitydriven transformation of schwertmannite and 2) re-adsorption to new phases formed upon Fe(II)-catalyzed transformation. The adsorbed As(III) has inhibited the extent of transformation and was partly released with the maximum release at $\mathrm{pH} 5(0.5 \%)$ in the absence of $\mathrm{Fe}(\mathrm{II})_{\mathrm{aq}}$.

\footnotetext{
* Corresponding author E-mail - susanta.paikaray@gmail.com
} 
Keywords- schwertmannite, acid mine drainage, lepidocrocite, goethite, arsenic, $\mathrm{Fe}(\mathrm{II})$ catalyzed transformation

\section{INTRODUCTION}

Schwertmannite is an abundant, poorly crystalline ferric oxyhydroxysulfate mineral $\left(\mathrm{Fe}_{8} \mathrm{O}_{8}(\mathrm{OH})_{\mathrm{x}}\left(\mathrm{SO}_{4}\right)_{\mathrm{y}}\right.$, where $\mathrm{x}=8-2 \mathrm{y}$ and $\mathrm{y}$ ranges between 0.75 and 2.58 (Bigham et al., 1990, Caraballo et al., 2013). It precipitates from $\mathrm{SO}_{4}{ }^{2-}$ and $\mathrm{Fe}^{3+}$-enriched acidic water around acid mine drainage (AMD) localities (Bigham et al., 1990, 1994; Peine et al., 2000), and in acid sulfate soils (Burton et al., 2007; Jones, et al., 2009; Collins et al., 2010).

Schwertmannite remains stable for years under acidic conditions (Bigham et al., 1996; Regenspurg et al., 2004; Jönsson et al., 2005, 2006; Peretyazhko et al., 2009). It will be transformed to goethite through an alkalinity-driven pathway, irrespective of the redox conditions. The transformation rate depends on pH (Bigham et al., 1996, Regenspurg et al., 2004). Alternatively, in the presence of aqueous Fe(II), a Fe(II)_catalysed pathway exists. The transformation is driven by electron transfer from adsorbed Fe(II) with goethite as the transformation product (Burton et al., 2008, 2010).

Field studies demonstrated enrichment of schwertmannite with arsenic (As) around AMD localities (Webster et al., 1998; Morin et al., 2003; Fukushi et al., 2003, 2004; Casiot et al., 2005; Egal et al., 2009; French et al., 2012). Schwertmannite is an excellent scavenger for both As(III) and As(V) (Burton et al., 2009; Paikaray et al., 2011, 2012, 2014) and was successfully used for the removal of As species from contaminated mine water (Janneck et al., 2011). Both adsorbed As(V) and As(III) have shown to decelerate schwertmannite transformation in oxic (Fukushi et al., 2003; Schwertmann and Carlson, 2005; Liao et al. 2011; Paikaray and Peiffer, 2012) as well as in anoxic Fe(II)-dominated environments (Burton et al., 2008, 2010).

The reason for stabilization of schwertmannite upon As uptake is still under debate. Reductive transformation by $\mathrm{Fe}(\mathrm{II})_{\mathrm{aq}}$ can be inhibited through adsorption of constituents of 
natural waters such as silica $(\mathrm{Si})$ or dissolved organic carbon (DOC) (Jones et al., 2009; Collins et al., 2010; Burton and Johnston, 2012), an observation that is proposed to explain the occurrence of stable schwertmannite in Si-rich acid sulfate coastal plains in Eastern Australia (Collins et al., 2010). Incomplete transformation of schwertmannite to goethite (72\% goethite) was reported under $\mathrm{Fe}(\mathrm{II})$-rich reducing conditions within 9 days after exposure to $10 \mathrm{mM} \mathrm{Fe}(\mathrm{II})_{\mathrm{aq}}$ and $1 \mathrm{mM}$ As at $\mathrm{pH} 6.5$ as compared to As(III)-free systems (97\% goethite) (Burton et al., 2010). Hence, As(III) may occupy sorption sites that are responsible for $\mathrm{Fe}(\mathrm{II})$ catalyzed transformation.

However, $\mathrm{pH}$ values in reducing environments where schwertmannite occurs may be lower than pH 6.5 (Regenspurg et al., 2004), but still higher than the pH stability window of schwertmannite (pH 3.0-4.5) which feeds back on both transformation products and the sorption edge of $\mathrm{Fe}(\mathrm{II})$ onto schwertmannite. Moreover, in the previous study on $\mathrm{Fe}(\mathrm{II})$ catalyzed SHM transformation (Burton et al., 2008), the schwertmannite used that had been synthesized in a pure abiotic way through rapid oxidation by $\mathrm{H}_{2} \mathrm{O}_{2}$. Striking differences in reactivity were observed between biogenic and abiotically synthesized schwertmannite (Paikaray et al., 2011) due to the large difference in specific surface area.

In this work, we therefore investigate the stability of biogenic schwertmannite after reaction with $\mathrm{As}(\mathrm{III})$ in a $\mathrm{pH}$ range between $\mathrm{pH} 5.0$ and 6.9 and at $\mathrm{Fe}(\mathrm{II})_{\mathrm{aq}}$ concentrations between 0.4 and $1.0 \mathrm{mM}$, using microscopic (electron microscopy) and spectroscopic (FTIR and Mössbauer) techniques, X-ray diffraction, and wet chemical analysis of the release rates of dissolution products.

\section{MATERIALS AND METHODS}

\subsection{Schwertmannite synthesis}

Schwertmannite (SHM) was synthesized through bacterial oxidation of $\mathrm{Fe}^{2+}$ from $\mathrm{SO}_{4}{ }^{2-}$-rich lignite mine effluents between $\mathrm{pH} 2.9$ and 3.2 in a schwertmannite producing 
treatment-plant (GEOS, Freiberg, Germany) (Glombitza et al., 2007). Batches including the acidophilic bacterial species Acidithiobacilius ferrooxidans were incubated at $30{ }^{\circ} \mathrm{C}$ and 130 rpm for $\sim 1$ month on a rotary shaker at $130 \mathrm{rpm}$ until the $\mathrm{Fe}(\mathrm{II})$ concentrations remained constant. The brownish yellow precipitates were then separated by centrifugation and air dried at room temperature $\left(20-25{ }^{\circ} \mathrm{C}\right)$, sieved $(<63 \mu \mathrm{m})$ and used directly without further treatment for ageing experiments and characterization. $0.92 \mathrm{wt} \%$ As(III) was loaded onto part of the schwertmannite through a 5 day batch equilibrium processes at $\mathrm{pH} 3.0$, oven dried at $30-40{ }^{\circ} \mathrm{C}$ and stored at RT, called SHM-As. X-ray absorption spectroscopic studies revealed the presence of $\mathrm{As}(\mathrm{III})( \pm 5 \% \mathrm{As}(\mathrm{V}))$ on schwertmannite (Paikaray et al., 2011, 2012). The chemical composition was determined from $\mathrm{Fe}$ and $\mathrm{S}$ concentrations measured after dissolution in $1.0 \mathrm{~N} \mathrm{HCl}$ (Winland et al., 1991) using the equation $\mathrm{Fe}_{8} \mathrm{O}_{8}(\mathrm{OH})_{\mathrm{x}}\left(\mathrm{SO}_{4}\right)_{\mathrm{y}} ; \mathrm{x}=8-2 \mathrm{y}$, $1<y<1.75$ (Bigham et al., 1990), while mineralogy and surface functional groups were studied by X-ray diffraction (XRD) and Fourier Transform Infrared (FTIR) techniques.

\subsection{Transformation experiments}

The reactor vials were conditioned in $10 \%(\mathrm{v} / \mathrm{v}) \mathrm{HNO}_{3}$ overnight and then rinsed with milli-Q water $(18 \mathrm{~m} \Omega)$ for 4 times before starting the experiment. All chemicals were of analytical grade with the highest purity and most solutions were prepared fresh when required using $\mathrm{N}_{2}$ purged milli-Q $\mathrm{H}_{2} \mathrm{O}$. Nitrogen purging was done using high purity $\mathrm{N}_{2}$ gas $(95 \%$ $\mathrm{N}_{2}+5 \% \mathrm{H}_{2}$ ) for at least $2 \mathrm{~h}$ to ensure complete deoxygenation. The glove box was preconditioned for $\sim 2$ weeks by using ultrapure $\mathrm{N}_{2}$ gas before starting the experiments and flushed 2-3 times daily during the experiments. Oxygen levels were measured regularly by using gas chromatography (GC 6890, Agilent) and found to be zero.

Ageing experiments were conducted for $202 \mathrm{~h}$ using $0.25 \mathrm{~g}$ of SHM and SHM-As in $25 \mathrm{ml} \mathrm{O}$-free milli-Q $\mathrm{H}_{2} \mathrm{O}\left(10 \mathrm{~g} \mathrm{~L}^{-1}\right)$ in glass serum reactor vials. The $\mathrm{pH}$ of the solutions were maintained at $\mathrm{pH} 5.0,6.0$ and 6.9 by using acetate $\left(\mathrm{pK}_{\mathrm{a}}=4.76\right), 2-(\mathrm{N}-$ 
Morpholino)ethanesulfonic acid monohydrate (MES) $\left(\mathrm{pK}_{\mathrm{a}}=6.1\right)$ and Piperazine-1,4-bis(2ethanesulfonic acid) (PIPES) $\left(\mathrm{pK}_{\mathrm{a}}=6.8\right)$ buffers, respectively prior to addition of SHM or SHM-As. Appropriate quantities of $\mathrm{FeCl}_{2}$ stock solutions $(100 \mathrm{mM})$ were added inside the glove box to maintain $\mathrm{Fe}(\mathrm{II})_{\mathrm{aq}}$ concentrations at $0.4,0.7$ and $1.0 \mathrm{mM}$. After addition of $\mathrm{Fe}(\mathrm{II})_{\mathrm{aq}}$, the reactor vials were crimp-sealed immediately and removed from the glove box for end-to-end tumbling using an overhead shaker. Pairs of reactor vials were collected in regular intervals of $\sim 4 \mathrm{~h}$ initially until $36 \mathrm{~h}$ and then of $\sim 10-12 \mathrm{~h}$ until the ageing experiments were concluded. The aqueous phase was separated by filtration $(<0.45 \mu \mathrm{m}$ ROTH filter $)$, the solid phase was dried at RT inside the glove-box and stored in crimp-sealed vials to restrict exposure to atmospheric $\mathrm{O}_{2}$ until analysis.

\subsection{Solid phase analysis}

Mineralogical investigations were carried out with a D-5000 X-ray diffractometer (SIEMENS, Germany) using a Co $\mathrm{K} \alpha$ radiation $(\lambda=0.179 \mathrm{~nm})$ source. The samples were scanned four times between $10-80^{\circ} 2 \theta$ using a $0.20{ }^{\circ} 2 \theta$ step size and 15 second count time. Averaged diffractograms are presented here. Surface functional groups were examined with FTIR spectroscopy (Vector 22, Bruker Optik GmbH, Germany). Pellets were prepared by homogenous mixing of $2 \mathrm{mg}$ of sample with $200 \mathrm{mg}$ of $\mathrm{KBr}$ at $8 \mathrm{kbar}$ pressure and subsequently subjected to infrared radiation between 350 and $2000 \mathrm{~cm}^{-1}$ with $1 \mathrm{~cm}^{-1}$ resolution. A total of 32 scans were collected for each measurement in transmission mode and the background spectra were subtracted automatically by background scans before running the samples. For electron microscopy, powdered samples were fixed on carbon tape, which was sputtered in a Cressington Sputter Coater $208 \mathrm{HR}$ with $1.3 \mathrm{~nm}$ Platin ( 1 min, $40 \mathrm{~mA})$ and imaged at $3 \mathrm{kV}$ by a LEO 1530 SEM equipped with a Shotky Cathode and a GEMINI column with $\mathrm{ZrO}_{2}$ radiation source (Zeiss, Germany). The specific surface area (SSA) was determined by a five point $\mathrm{N}_{2}$ adsorption isotherm (BET method) and found to be 14.7 and $17.1 \mathrm{~m}^{2} \mathrm{~g}^{-1}$ for SHM and SHM-As, respectively. ${ }^{57} \mathrm{Fe}-$ Mössbauer spectra were obtained with a Wissel 
(Germany) spectrometer. The solid phase samples were mounted on acylic glass holders. The analysis was performed with a ${ }^{57} \mathrm{Co}$ source in $\mathrm{Rh}$ matrix at room temperature (RT) and at $\sim 5$ $\mathrm{K}$ in transmission mode. Samples were cooled using a Janis (USA) cryostat. Spectra were calibrated against the spectrum of an $\alpha-\mathrm{Fe}(0)$ foil at room temperature and interpreted using the Recoil ${ }^{\circledR}$ software and the Voigt-based fitting method.

\subsection{Aqueous phase analysis}

Iron $(\mathrm{Fe}(\mathrm{T})$ and $\mathrm{Fe}(\mathrm{II}))$ and $\mathrm{SO}_{4}{ }^{2-}$ measurements were done spectrophotometrically (Cary 1E, Varian Analytical Instruments, Varian GmbH, Darmstadt, Germany) at $512 \mathrm{~nm}$ and $420 \mathrm{~nm}$ wavelength, respectively using the 1, 10-phenanthroline method (Tamura et al., 1974) for $\mathrm{Fe}$ and the $\mathrm{BaCl}_{2}$-Gelatin method for $\mathrm{SO}_{4}$ (Tabatabai, 1974). Iron(III) concentrations were determined by subtracting $\mathrm{Fe}(\mathrm{II})$ from total $\mathrm{Fe}(\mathrm{Fe}(\mathrm{T}))$. The $\mathrm{pH}$ was measured by using a precalibrated (pH 4.0 and 7.0 buffers) Mettler Toledo Inlab 412 electrode. An atomic absorption spectrophotometer (AAS) equipped with graphite furnace (AAS ZEEnit 60, Analytik Jena AG, Germany) was used to measure As concentrations at $193.7 \mathrm{~nm}$ wavelength under RT condition.

\section{RESULTS}

\subsection{Characterization of schwertmannites}

SEM images revealed acicular spines on smooth spheroidal particles that are characteristic of schwertmannite for SHM, and a slightly changed morphology upon As(III) sorption (SHM-As) (Table 1, Fig. 1). Their amorphous nature is evident from broadened peaks in diffractograms with smaller peaks at $\sim 0.146, \sim 0.152, \sim 0.168, \sim 0.193, \sim 0.230, \sim 0.326$ and $\sim 0.545 \mathrm{~nm}$ and the characteristic maximum intensity at $\sim 0.258 \mathrm{~nm}$. Three infrared (IR) $\mathrm{SO}_{4}{ }^{2-}$ absorption bands characteristic of unaltered schwertmannite (Paikaray and Peiffer, 2010; Paikaray et al., 2011, 2012) were observed at $1120 \mathrm{~cm}^{-1}\left(v_{3}\left(\mathrm{SO}_{4}\right)\right), 981 \mathrm{~cm}^{-1}\left(v_{1}\left(\mathrm{SO}_{4}\right)\right)$ and $610 \mathrm{~cm}^{-1}\left(v_{4}\left(\mathrm{SO}_{4}\right)\right)$ in both SHM and SHM-As, with Fe-O vibrations at 410 and $700 \mathrm{~cm}^{-1}$. 
Arsenic(III) uptake possibly resulted in a new low intensity IR band at $\sim 1385 \mathrm{~cm}^{-1}$ and a shifting of the $0.326 \mathrm{~nm}$ XRD peak position (SHM) to $0.341 \mathrm{~nm}$ (SHM-As) (Paikaray et al., 2011, 2012). Mössbauer spectra showed no significant difference between SHM and SHMAs, which suggests that As is predominantly surface sorbed with no significant incorporation into the crystal structure (Tables 2 and 3 and Fig. 4 and 5, see discussion below) although traces of structural binding are reflected in the XRD peak shifting and appearance of $\sim 1385$ $\mathrm{cm}^{-1}$ IR band in case of SHM-As. Chemical analysis showed 7.4 \pm 0.65 and 7.5 $\pm 0.66 \mathrm{mmol} \mathrm{g}$ Fe and $1.55 \pm 0.02$ and $1.44 \pm 0.02 \mathrm{mmol} \mathrm{g}^{-1} \mathrm{SO}_{4}{ }^{2-}$ for SHM and SHM-As, respectively $(\mathrm{n}=2)$. The Fe:S molar ratios of 6.3 and 6.4 yielded $\mathrm{Fe}_{8} \mathrm{O}_{8}(\mathrm{OH})_{4.64}\left(\mathrm{SO}_{4}\right)_{1.68}$ and $\mathrm{Fe}_{8} \mathrm{O}_{8}(\mathrm{OH})_{4.82}\left(\mathrm{SO}_{4}\right)_{1.59}$ as the stoichiometric formulas for SHM and SHM-As, respectively. The estimated schwertmannite compositions are consistent with earlier studies (Regenspurg et al., 2004; Burton et al., 2008; Liao et al., 2011) and satisfy the general stoichiometry proposed by Bigham et al. (1990, 1994).

\subsection{Product formation}

X-ray diffractograms showed schwertmannite as the only end product after ageing in the presence or absence of $\mathrm{Fe}(\mathrm{II})_{\mathrm{aq}}$ at $\mathrm{pH} 5$ (Fig. 2), irrespective of whether it was loaded with As(III) or not. XRD patterns did not show any evidence for lepidocrocite or goethite formation up to $0.7 \mathrm{mM} \mathrm{Fe}(\mathrm{II})_{\mathrm{aq}}$ at $\mathrm{pH} 6$ and 6.9 (Fig. S1), whereas lepidocrocite along with traces of goethite were observed after $80 \mathrm{~h}$ of ageing of SHM at $1 \mathrm{mM} \mathrm{Fe}(\mathrm{II})_{\mathrm{aq}}$ (Fig. $2 \mathrm{~B}$ and Fig. S1). Lepidocrocite was the only detectable additional product at $1 \mathrm{mM} \mathrm{Fe}(\mathrm{II})_{\mathrm{aq}}$ in case of SHM-As and appeared after $202 \mathrm{~h}$ at $\mathrm{pH} 6$ and after $82 \mathrm{~h}$ at 6.9 .

Similar results were obtained from IR spectra (Fig. 2A and Fig. S2). Signatures of schwertmannite at $410 \mathrm{~cm}^{-1}(\mathrm{Fe}-\mathrm{O}), 610 \mathrm{~cm}^{-1}\left(v_{4}\left(\mathrm{SO}_{4}\right)\right), 700 \mathrm{~cm}^{-1}(\mathrm{Fe}-\mathrm{O}), 981 \mathrm{~cm}^{-1}\left(v_{1}\left(\mathrm{SO}_{4}\right)\right)$, and $1050 / 1120 \mathrm{~cm}^{-1}\left(v_{3}\left(\mathrm{SO}_{4}\right)\right)$ were found in all samples after $202 \mathrm{~h}$ of ageing in the presence of $1 \mathrm{mM} \mathrm{Fe}(\mathrm{II})_{\mathrm{aq}}$, indicating the persistence of original schwertmannite until this time. The IR spectra provided no evidence for the formation of new phases at $\mathrm{Fe}(\mathrm{II})_{\mathrm{aq}}$ concentrations $\leq 0.7$ 
$\mathrm{mM}$, irrespective of $\mathrm{pH}$ (Fig. S2). The decrease in $\mathrm{v}_{4}\left(\mathrm{SO}_{4}\right)$ band intensity under these conditions is probably due to $\mathrm{SO}_{4}{ }^{2-}$ desorption (Paikaray and Peiffer, 2010) which is also supported by an increase in $\mathrm{SO}_{4}{ }^{2-}$ release with time and with $\mathrm{Fe}(\mathrm{II})_{\text {aq }}$ concentration (see section 3.3). In the presence of $1 \mathrm{mM} \mathrm{Fe}(\mathrm{III})_{\mathrm{aq}}$, the appearance of a new band at $1020 \mathrm{~cm}^{-1}$ after $154 \mathrm{~h}$ at $\mathrm{pH} 6$ and after $58 \mathrm{~h}$ at $\mathrm{pH} 6.9$ indicates the formation of lepidocrocite. Traces of goethite $\left(792\right.$ and $\left.890 \mathrm{~cm}^{-1}\right)$ were detected after $154 \mathrm{~h}$ in the presence of $1 \mathrm{mM} \mathrm{Fe}(\mathrm{II})_{\mathrm{aq}}$ at both $\mathrm{pH}$ values for As(III)-free schwertmannite (Fig. S2). No goethite IR bands were found in the case of SHM-As, while lepidocrocite was clearly detectable after $202 \mathrm{~h}$ at pH 6 and after $58 \mathrm{~h}$ at 6.9. The low intensity $\mathrm{COO}^{-}$vibration $\left(1400 \mathrm{~cm}^{-1}\right)$ which intensified at $\mathrm{pH} 5$ together with the $\mathrm{C}-\mathrm{O}$ stretching vibration $\left(1520 \mathrm{~cm}^{-1}\right)$ can be explained by the acetate buffer used in the experiments at this $\mathrm{pH}$. Both $\mathrm{XRD}$ and $\mathrm{IR}$ data suggest a faster and a more complete transformation in the absence of $\mathrm{As}(\mathrm{III})$ that is further enhanced by increases in $\mathrm{pH}$ and dissolved $\mathrm{Fe}(\mathrm{II})_{\mathrm{aq}}$.

Microscopy reveals that the schwertmannite morphology changes after $202 \mathrm{~h}$ exposure at $\mathrm{pH} 5$ at all $\mathrm{Fe}(\mathrm{II})_{\mathrm{aq}}$ concentrations but there is no evidence for the formation of new mineral phases (Fig. 3). At pH 6 at concentrations of $\mathrm{Fe}(\mathrm{II})_{\mathrm{aq}} \leq 0.7 \mathrm{mM}$, ageing for $202 \mathrm{~h}$ also caused morphological degradation. In contrast to IR and XRD observations, no distinct new phases were visible after that time (Fig. S3 to Fig. S5). Likewise, schwertmannite underwent morphological change at $\mathrm{pH} 6.9$ and $\mathrm{Fe}(\mathrm{II})_{\mathrm{aq}} \leq 0.4 \mathrm{mM}$. However, at $1 \mathrm{mM} \mathrm{Fe}(\mathrm{II})_{\mathrm{aq}}$ and $\mathrm{pH} 6.0$ (Fig. 3) and at $0.7 \mathrm{mM} \mathrm{Fe(II)})_{\mathrm{aq}}$ and pH 6.9 (Fig. S3), lepidocrocite crystals were clearly visible with remarkable morphological difference between SHM-As and SHM specimens. The lepidocrocite displayed a platy tabular morphology in SHM speciments, and a needle shaped morphology in SHM-As specimens.

Mössbauer spectra of the initial SHM and SHM-As were compared to spectra obtained from SHM and SHM-As reacted for $202 \mathrm{~h}$ at $\mathrm{pH} 6$ and 6.9 in the presence of $1.0 \mathrm{mM} \mathrm{Fe}(\mathrm{II})_{\mathrm{aq}}$ and confirm the formation of lepidocrocite and goethite at both $\mathrm{pH}$ levels, for pure SHM and 
SHM-As. Fig. 4 shows Mössbauer spectra obtained at $\sim 5 \mathrm{~K}$. The corresponding Mössbauer parameters are shown in Table 2. At this temperature, schwertmannite, lepidocrocite, and goethite are magnetically ordered and manifest themselves as six-line subspectra (sextets) in the Mössbauer spectra. The lines of the three mineral phases' subspectra overlap and the subspectra are not well-resolved. Instead, mineral phases in addition to the initial SHM and SHM-As are indicated by broadened lines and shoulders. The reacted spectra in both the SHM and SHM-As system need a phase with an increased hyperfine field $\mathrm{B}_{\mathrm{hf}}$ which were modelled as lepidocrocite and goethite based on their occurrence in X-ray diffractograms and IR spectra. At $\mathrm{pH}$ 6.0, more schwertmannite was transformed in the SHM-As system (90\%) compared to SHM (84\%), while more lepidocrocite (66\%) and less goethite (24\%) formed in SHM-As compared to pure SHM (45 and 39\%, respectively). At pH 6.9, schwertmannite was transformed completely into lepidocrocite and goethite from both SHM and SHM-As, and lepidocrocite and goethite formed in the same relative proportions in both systems (61 and $39 \%$, respectively).

Spectra taken at room temperature (Fig. 5, Table 3, and Fig. S6) provide information about the degree of crystallinity and/or impurities of the goethite phase. At room temperature, both schwertmannite and lepidocrocite are paramagnetic and manifest themselves as two-line subspectra (doublets) in the Mössbauer spectra. Well-crystalline, pure goethite is magnetically ordered and would show up as a sextet. Goethite, however, can be superparamagnetic at that temperature (doublet) in the case of a small particle size (generally below $30 \mathrm{~nm}$ ) or magnetic ordering can be suppressed in case of a lower degree of crystallinity and/or impurities (De Grave et al. 2002). The Mössbauer spectra of reacted SHM showed a sextet, although at lesser abundance than the goethite in the $5 \mathrm{~K}$ spectra. This can be explained with part of the goethite being superparamagnetic, and part exhibiting a degree of crystallinity which also might have caused its detection in the XRD and IR spectra. The Mössbauer spectra of reacted SHM-As show no sextets and therefore indicate that goethite is of a low degree of crystallinity and/or 
contains impurities such as As incorporation upon reprecipitation. This observation may also explain why goethite peaks were not detectable in XRD and IR studies of SHM-As transformation products.

\subsection{Dynamics of $\mathrm{SO}_{4}{ }^{2-}, \mathrm{Fe}(\mathrm{II})$, and $\mathrm{As}$}

A rapid increase of sulfate concentration occurred within the first $4 \mathrm{~h}$ after suspension of the solid phase (Fig. 6). In the absence of $\mathrm{Fe}(\mathrm{II})_{\mathrm{aq}}$ the amount of initially released $\mathrm{SO}_{4}{ }^{2-}$ increased from $21 \%\left(0.33 \pm 0.03 \mathrm{mmol} \mathrm{g}^{-1}\right)$ to $36 \%\left(0.55 \pm 0.003 \mathrm{mmol} \mathrm{g}^{-1}\right)$ as the $\mathrm{pH}$ increased from 5.0 to 6.9 in case of SHM and from $17 \%\left(0.25 \pm 0.003 \mathrm{mmol} \mathrm{g}^{-1}\right)$ to $34 \%(0.49 \pm 0.01$ mmol $\mathrm{g}^{-1}$ ) in case of SHM-As (Fig. 6, Fig. S7). Increasing Fe(II) $)_{\mathrm{aq}}$ from 0 to $1 \mathrm{mM}$ did not significantly influence the initial $\mathrm{SO}_{4}{ }^{2-}$ release. Sulfate concentrations remained almost constant for the entire time period at $\mathrm{pH} 5$ for both SHM and SHM-As at all Fe(II) $)_{\mathrm{aq}}$ concentrations. However, a significant increase in $\mathrm{SO}_{4}{ }^{2-}$ concentration was observed for both specimens at $\mathrm{pH} 6\left(\sim 0.7 \mathrm{mmol} \mathrm{g}^{-1}\right)$ and at $\mathrm{pH} 6.9\left(\sim 0.9 \mathrm{mmol} \mathrm{g}^{-1}\right)$ as $\mathrm{Fe}(\mathrm{II})_{\text {aq }}$ concentrations increased to $1.0 \mathrm{mM}$. Hence, the maximum release of $\mathrm{SO}_{4}{ }^{2-}$ after $202 \mathrm{~h}$ at $\mathrm{pH} 6.9$ in the presence of $1.0 \mathrm{mM} \mathrm{Fe}(\mathrm{II})_{\mathrm{aq}}$ makes up $\sim 45 \%$ of the solid phase $\mathrm{SO}_{4}{ }^{2-}$ from both $\mathrm{SHM}$ and SHM-As (Fig. 6).

Similar to sulfate, a constant $\mathrm{Fe}(\mathrm{II})_{\mathrm{aq}}$ concentration was rapidly established for As-free schwertmannite (Fig. 7, see also Fig. S8). The extent of Fe(II) adsorption to schwertmannite loaded with As was largely reduced at $\mathrm{pH}$ 6.0, and equilibrium concentrations of $\mathrm{Fe}(\mathrm{II})_{\mathrm{aq}}$ remained significantly higher for SHM-As compared to pure SHM throughout the experiment at pH 6.9.

The arsenic concentration in solution increased with time in all experiments. The highest As release was found at $\mathrm{pH} 5$ in the absence of $\mathrm{Fe}(\mathrm{II})_{\mathrm{aq}}$ after $202 \mathrm{~h}$ of ageing, corresponding to $\sim 0.5 \%$ of the total adsorbed As (Fig. 8). The amount of released As decreased with increasing pH (Fig. 8 and Fig. S9) both in the absence and presence of Fe(II) $)_{\mathrm{aq}}$. Differences in the release patterns can be observed between conditions in the absence of 
$\mathrm{Fe}(\mathrm{II})$ and where $\mathrm{Fe}(\mathrm{II})$ was added. A continuous release of As occurred also in the presence of $\mathrm{Fe}(\mathrm{II})_{\mathrm{aq}}$ at $\mathrm{pH} \mathrm{5,6}$ and 6.9. While As concentrations at $\mathrm{Fe}(\mathrm{II})$-rich conditions remained below those at $\mathrm{Fe}(\mathrm{II})$-free conditions at $\mathrm{pH} 5$ and 6, final concentrations of As for $\mathrm{Fe}$ (II)-rich conditions at pH 6.9 were higher compared to the corresponding Fe(II)-free experiment (Fig. 8 and Fig. S9). There is a general trend for the As release from schwertmannite to be lower if the $\mathrm{pH}$ increased from 5.0 to 6.9. In contrast, the addition of Fe(II) lead to an increase of As release relative to conditions where transformation occurred in the absence of Fe(II) and this increase was more pronounced at higher $\mathrm{pH}$.

At $\mathrm{pH}$, the As release was almost independent of the addition of Fe(II) except for a marginal difference in As concentrations after $\sim 100 \mathrm{~h}$ (Fig. 8, $\mathrm{c}(\mathrm{Fe}$ (II) $=0 \mathrm{mM}$ and $1.0 \mathrm{mM}$, respectively). At $\mathrm{pH} 6$, As release remained almost constant after 75-100 h at $\leq 0.4 \mathrm{mM}$ $\mathrm{Fe}(\mathrm{II})_{\mathrm{aq}}$ contrary to the steady release until $202 \mathrm{~h}$ at $\geq 0.7 \mathrm{mM} \mathrm{Fe}(\mathrm{II})_{\mathrm{aq}}$ (Fig. 8 and Fig. S9)._At $\mathrm{pH} 6.9$, increasing addition of $\mathrm{Fe}(\mathrm{II})_{\mathrm{aq}}$ has a distinct effect on As release where As release at higher $\mathrm{Fe}(\mathrm{II})_{\mathrm{aq}}$ concentrations crossed over that at low $\mathrm{Fe}(\mathrm{II})_{\mathrm{aq}}$ as aging time increases (see $\mathrm{c}(\mathrm{Fe}(\mathrm{II})=0$ vs. $1.0 \mathrm{mM}$; Fig. 8 and 0.4 vs. $0.7 \mathrm{mM}$; Fig. S9). This leads to an increase of the As concentration after $202 \mathrm{~h}$ in the $1 \mathrm{mM}$ Fe(II) treatment relative to the control treatment $\left(\mathrm{Fe}(\mathrm{II})_{\mathrm{aq}}=0 \mathrm{mM}\right)$ by a factor of $\sim 4.2\left(\mathrm{c}(\mathrm{As})_{202 \mathrm{~h}}-\mathrm{c}(\mathrm{As})_{4 \mathrm{~h}}\right)$.

\section{DISCUSSION}

\subsection{Transformation of schwertmannite in the presence of $\mathrm{Fe}(\mathrm{II})$}

Surface coverage with $\mathrm{Fe}(\mathrm{II})$ seems to drive the transformation rate and product formation, which was highest at the highest amount of $\mathrm{Fe}(\mathrm{II})_{\mathrm{aq}}$ added, and at the highest $\mathrm{pH}$ where adsorption of Fe(II) to the surface of ferric (hydr)oxides is highest (cf. Fig. 7). In contrast, in the absence of $\mathrm{Fe}(\mathrm{II})_{\mathrm{aq}}$, no new phases could be observed, irrespective of the $\mathrm{pH}$ (Fig. S3).

Previous studies on Fe(II)-catalyzed ferrihydrite transformation (Tronc et al., 1992; Burke and Banwart, 2000; Liu et al., 2005. 2008, 2009) distinguish between two 
transformation pathways: solid-state transformation leading to hematite and dissolutionreprecipitation leading to the formation of goethite or lepidocrocite. The precursor and the end product need to have isomorphic crystal structure in a solid-state transformation process, which is relatively slow and takes months to complete (Liu et al., 2008, 2009). In the present experiments, the transformation occurred within a short time span (days). Adsorption of Fe(II) on iron oxide mineral surfaces is believed to form mixed $\mathrm{Fe}(\mathrm{II})-\mathrm{Fe}(\mathrm{III})$ surfaces such as magnetite or infer electron transfer between sorbed $\mathrm{Fe}(\mathrm{II})$ and the $\mathrm{Fe}(\mathrm{III})$ crystal lattice (Williams and Scherer, 2004; Larese-Casanova and Scherer, 2007). Formation of magnetite is not evident from this study (at least at the time scale of the analysis) indicating that the adsorbed $\mathrm{Fe}(\mathrm{II})$ caused partial dissolution of schwertmannite.

Schwertmannite belongs to the tetragonal crystal system (Cornell and Schwertmann, 2003) and the two products observed, i.e., lepidocrocite and goethite, share orthorhombic crystal structure. Such a transformation pathway requires dissolution of the precursor mineral and subsequent reprecipitation of a new phase (Liu et al., 2009). Lepidocrocite is reported to act as a precursor for goethite being thermodynamically unstable with respect to goethite (Hansel et al., 2005). Hence, formation of lepidocrocite in the initial stage and subsequent conversion to goethite might be one possible pathway for Fe(II)-catalyzed transformation of schwertmannite, especially when the transformation rate is slower at lower $\mathrm{Fe}(\mathrm{II})_{\mathrm{aq}}$ levels.

As expected, the fraction of $\mathrm{Fe}(\mathrm{II})$ adsorbed after $202 \mathrm{~h}$ increased with $\mathrm{pH}$, i.e., with increasing fraction of sorption sites at the schwertmannite surface. Residual $\mathrm{Fe}(\mathrm{II})_{\mathrm{aq}}$ concentrations were almost constant throughout the studied period (especially for SHM and 1 $\mathrm{mM} \mathrm{Fe}(\mathrm{II})_{\mathrm{aq}}$ SHM-As) which suggests rapid $\mathrm{Fe}(\mathrm{II})_{\mathrm{aq}}$ adsorption upon contact with schwertmannite (Fig. 7). Fe(II)-catalyzed SHM transformation does not lead to a depletion of aqueous $\mathrm{Fe}(\mathrm{II})$, which we explain with the conceptual model of a redox-driven conveyor belt (Handler et al., 2009). In this model a repeated series of i) sorption onto the surface of a ferric (hydr)oxide, ii) electron transfer between adsorbed $\mathrm{Fe}^{2+}$ and $\mathrm{Fe}^{3+}$ at the surface of ferric 
(hydr)oxides, iii) growth of a new layer of oxide, iv) movement of the injected electron through the bulk mineral, and $\mathrm{v}$ ) release of $\mathrm{Fe}^{2+}$ at a separate site is proposed. These conditions allow for the formation of thermodynamically more stable minerals lepidocrocite and goethite.

Our study contrasts with earlier work by Burton et al. (2008) who observed goethite as the dominant phase at $\mathrm{pH} 6.5$ using $\mathrm{XRD}$. We propose that these difference are due to a difference in surface coverage with Fe(II). The biogenic SHM used has a higher surface area compared to SHM generated with $\mathrm{H}_{2} \mathrm{O}_{2}$ in the study by Burton et al (2008) (14.7 vs. $5.3 \mathrm{~m}^{2} \mathrm{~g}^{-}$ ${ }^{1}$, Paikaray et al, 2011). Together with a higher solid-solution ratio $\left(10 \mathrm{~g} \mathrm{~L}^{-1}\right.$ vs. $\left.5 \mathrm{~g} \mathrm{~L}^{-1}\right)$ and a lower concentration of $\mathrm{Fe}(\mathrm{II})_{\mathrm{aq}}$ used in this study $(\leq 1.0 \mathrm{mM}$ vs. $\geq 1.0 \mathrm{mM})$, the extent of surface coverage with $\mathrm{Fe}(\mathrm{II})$ was presumably distinctly lower in this study as compared to Burton et al (2008). This assumption is supported by the complete release of schwertmannite $\mathrm{SO}_{4}{ }^{2-}$ observed by Burton et al. (2008) at $\mathrm{pH}>6$ and $\mathrm{Fe}(\mathrm{II})_{\mathrm{aq}}>1.0 \mathrm{mM}$, while $>50 \% \mathrm{SO}_{4}{ }^{2-}$ still remained associated with schwertmannite after $202 \mathrm{~h}$ ageing in this study. Sulfate release rates determined in Burton et al (2008) were directly correlated with goethite formation rates.

We propose that the transformation rate of SHM to goethite as the more stable transformation product is kinetically related to the surface coverage with $\mathrm{Fe}(\mathrm{II})$. Following this rational, lepidocrocite will be an intermediate transformation product that forms at lower surface coverage with Fe(II) only. Similar observations were made by Pedersen et al. (2005) who observed complete ferrihydrite transformation into goethite at an aqueous $\mathrm{Fe}$ (II) concentration of $1 \mathrm{mM}$ within 2 days, while lepidocrocite was the main product at a lower $\mathrm{Fe}(\mathrm{II})$ concentration of $0.2 \mathrm{mM}$. Also these findings can be explained in terms of surface coverage by $\mathrm{Fe}(\mathrm{II})$.

Residual $\mathrm{Fe}(\mathrm{II})_{\mathrm{aq}}$ concentrations were always higher in the presence of SHM-As than in the presence of pure SHM except for the first few hours at pH 5 (Fig. 7 and Fig. S8). This indicates that $\mathrm{Fe}(\mathrm{II})_{\mathrm{aq}}$ adsorption is less favorable for SHM-As compared to pure SHM. It 
appears that pre-adsorption of As(III) has reduced the number of schwertmannite Fe(III) surface sites available for sorption of Fe(II) $)_{\mathrm{aq}}$ (Dixit and Hering, 2006; Catalano et al., 2011) that are essential to enable electron transfer process (Williams and Scherer, 2004) and also affected product formation with a substantial fraction of lepidocrocite instead of goethite.

Under conditions with presumably a much higher surface concentration of $\mathrm{Fe}(\mathrm{II})$ due to a higher initial $\mathrm{Fe}(\mathrm{II})_{\mathrm{aq}}$ concentration $(10 \mathrm{mM}), 0.1 \mathrm{M} \mathrm{NaCl}$ background solution, a higher $\mathrm{pH}$ (6.5), a lower solid-solution ratio (5 g/L) and with As(III) being initially in the aqueous phase, goethite was the only transformation product (Burton et al., 2010). We therefore propose that, similar to the results observed in the absence of As(III), the reduced surface coverage in our experiments compared to Burton et al. (2010) suppressed formation of goethite and also affected the crystallization process (needle shaped vs. platy tabular) of lepidocrocite (Fig. 3 and Fig. S3-S5). Similar observations were made in the presence of Si. Pre-adsorption of Si onto schwertmannite has been shown to block the surface sites for later $\mathrm{Fe}(\mathrm{II})$ adsorption and inhibited the $\mathrm{Fe}(\mathrm{II})$ catalyzed transformation compared to conditions with both $\mathrm{Si}$ and $\mathrm{Fe}(\mathrm{II})_{\mathrm{aq}}$ being initially in the aqueous solution (Jones et al., 2009; Burton and Johnston, 2012).

Previous studies demonstrate that adsorbed ions or constituents (e.g., Si and NOM) retard the $\mathrm{Fe}(\mathrm{III})$ crystallization process (Ostwald ripening) through either blocking dissolution sites within the Fe(III) mineral, inhibiting nucleation of more stable Fe(III) (hydr)oxide phases (Schwertmann and Cornell, 1991), or reducing the number of Fe doublecorner linkage by adsorbed ions such as Si (Doelsch et al., 2000). Similar effects can be expected also for $\mathrm{As}(\mathrm{III})$ species. It has been demonstrated that $\mathrm{As}(\mathrm{III})$ and $\mathrm{As}(\mathrm{V})$ are restricting the formation of ferric hydroxyl complexes ((Fe(III)- $\left.\mathrm{OH}^{-}\right)$(Majzlan and Myneni, 2005; Regenspurg and Peiffer, 2005). The As ions have a higher affinity for Fe(III) compared to other anions such as $\mathrm{SO}_{4}{ }^{2-}$ (Dzombak and Morel, 1990) and therefore may inhibit growth of 
new minerals after dissolution of schwertmannite (Carlson et al., 2002; Regenspurg and Peiffer, 2005).

\subsection{Dynamics of $\mathrm{As}(\mathrm{III})$ and $\mathrm{SO}_{4}{ }^{2-}$ release during schwertmannite transformation}

At low $\mathrm{pH}$ conditions, schwertmannite is stable with a high amount of $\mathrm{SO}_{4}{ }^{2-}$ found to be associated with the schwertmannite tunnel structure and bound to the surface (Bigham et al., 1990, 1996). As the $\mathrm{pH}$ increases, the schwertmannite structure destabilizes and $\mathrm{SO}_{4}{ }^{2-}$ is released (Bigham et al., 1996, Rose and Elliot, 2000; Jönsson et al., 2005; Regenspurg and Peiffer, 2005; Paikaray and Peiffer, 2010):

$$
\mathrm{Fe}_{8} \mathrm{O}_{8}(\mathrm{OH})_{8-2 x}\left(\mathrm{SO}_{4}\right)_{x}+2 x \mathrm{H}_{2} \mathrm{O} \rightarrow 8 \mathrm{FeOOH}+x \mathrm{SO}_{4}{ }^{2-}+2 x \mathrm{H}^{+}
$$

Hence, the observed release of $\mathrm{SO}_{4}{ }^{2-}$ in the absence of $\mathrm{Fe}(\mathrm{II})$ (Fig. 6) reflects the alkalinity-driven dissolution rate of schwertmannite.

A similar $\mathrm{pH}$ dependent release pattern would be also assumed for the oxyanion As(III). Instead, the As concentration in solution is decreasing with $\mathrm{pH}$ and, in the absence of $\mathrm{Fe}(\mathrm{II})_{\mathrm{aq}}$, a more or less constant value is achieved already at the first sampling time, i.e., after $4 \mathrm{~h}$ (Fig. 8). We, therefore, interpret the observed pattern in terms of a competition between $\mathrm{As}(\mathrm{III})$ and $\mathrm{SO}_{4}{ }^{2-}$ for sorption sites.

The As(III) uptake by schwertmannite is postulated to be a $\mathrm{pH}$ dependent exchange between $\mathrm{SO}_{4}{ }^{2-}$ and $\mathrm{As}(\mathrm{III})$ (Burton et al., 2009; Paikaray and Peiffer, 2010, Liao et al., 2011):

$$
>\mathrm{FeSO}_{4}^{-}+\mathrm{H}_{2} \mathrm{AsO}_{3}^{-} \leftrightarrow>\mathrm{FeAsO}_{3} \mathrm{H}^{-}+\mathrm{H}^{+}+\mathrm{SO}_{4}^{2-}
$$

where $>\mathrm{FeSO}_{4}$ and $>\mathrm{FeAsO}_{3} \mathrm{H}$ - denote surface complexes of $\mathrm{SO}_{4}{ }^{2-}$ and $\mathrm{AsO}_{3} \mathrm{H}_{2}{ }^{-}$.

Hence, with increasing $\mathrm{pH}$, the competitiveness of As for surface sites increases compared to $\mathrm{SO}_{4}{ }^{2-}$ (Burton et al., 2010; Liao et al., 2011) implying that the equilibrium is shifted towards the Fe(III)-As(III) surface complex.

In the presence of $\mathrm{Fe}(\mathrm{II})_{\mathrm{aq}}$, the pattern is different. At $\mathrm{pH} 6$ and $\mathrm{pH} 6.9$ dissolved As concentrations were even lower in the initial phase compared to $\mathrm{Fe}(\mathrm{II})_{\mathrm{aq}}$-free conditions but 
were increasing to similar or higher values after $202 \mathrm{~h}$. Following the model discussed above, $\mathrm{Fe}(\mathrm{II})_{\mathrm{aq}}$ seems to have interfered in the initial exchange reaction. Contrary to the alkalinitydriven transformation reaction in the presence of pure SHM, Fe(II)-catalyzed transformation appears to be a continuous process starting right after sorption equilibrium between Fe(II) and the solid phase has established. Hence, there is continuous formation of new mineral phases already in the initial phase of the experiment, which will lead to re-adsorption of As(III). Previous research demonstrates that adsorption of $\mathrm{Fe}(\mathrm{II})$ and its subsequent oxidation to $\mathrm{Fe}(\mathrm{III})$ favors adsorption of $\mathrm{As}(\mathrm{III})$ and $\mathrm{As}(\mathrm{V})$ on amorphous or crystalline $\mathrm{Fe}(\mathrm{III})$ (hydr)oxides through generation of new adsorption sites (Burke and Banwart, 2000; Dixit and Hering, 2003; Mukiibi, et al., 2008).

The final concentration of As reached after $202 \mathrm{~h}$ decreases with increasing initial concentration of $\mathrm{Fe}(\mathrm{II})_{\mathrm{aq}}$, which we propose is reflecting the extent of transformation (Fig. 6; Fig. S9). Mineralogical characterization of the phases formed after $202 \mathrm{~h}$ reveal the occurrence of new phases such as lepidocrocite and goethite. Pedersen et al. (2006) proposed that binding of As to crystalline phases like goethite is relatively stronger so that its subsequent release is minimal. We, therefore, assume that the surface complexes of As(III) formed on the new phases are stronger than those on the schwertmannite surface leading to the lower aqueous As(III) concentrations observed in the presence of $\mathrm{Fe}(\mathrm{II})$, with a minimum As(III) concentration at a $\mathrm{Fe}(\mathrm{II})$ concentration of $1 \mathrm{mM}$. Nevertheless, the temporal development of As(III) concentration was similar to that in the presence of pure SHM, which we interpret as a simultaneous release of As from schwertmannite transformed via the alkalinity driven transformation path.

\section{CONCLUSIONS}

This study shows that schwertmannite transformation proceeded through an alkalinitydriven pathway releasing sulfate and a Fe(II)-catalyzed pathway that generated lepidocrocite and goethite within days. As(III) concentrations released from As-enriched schwertmannite 
are controlled by two mechanisms: 1) exchange of As(III) for sulfate upon alkalinity-driven transformation of schwertmannite, and 2) re-adsorption to the new phases formed upon $\mathrm{Fe}(\mathrm{II})$ catalyzed transformation.

The extent of transformation depended on $\mathrm{pH}$ and the concentration of $\mathrm{Fe}(\mathrm{II})_{\mathrm{aq}}$. Our results provide evidence that the extent of surface coverage is decisive in controlling the transformation product. We propose that the relatively low concentration of $\mathrm{Fe}(\mathrm{II})_{\mathrm{aq}}$ used in this study as well as the reduction of surface sites available for adsorption of $\mathrm{Fe}$ (II) by preadsorption of As(III) allowed for the formation of the less stable lepidocrocite. However, indepth research on the relationship between $\mathrm{Fe}(\mathrm{II})$ surface coverage and transformation rate as well as product formation is missing.

Extrapolation of these results to natural conditions where competing ions or constituents are abundant $\left(\mathrm{Ca}^{2+}, \mathrm{Si}, \mathrm{DOC}\right)$ implies that the $\mathrm{Fe}(\mathrm{II})$ catalyzed transformation pathway is of less importance and that lepidocrocite is the major transformation product of this pathway in the initial transformation process. On the other hand, occurrence of $\mathrm{Fe}(\mathrm{II})$ in anoxic pore waters (e.g., mining lake sediments) are indicative for the production of alkalinity (e. g. Peine et al, 2000), which is then driving schwertmannite transformation. Arsenic(III) released from schwertmannite may then re-adsorb to both lepidocrcite and goethite. Our study suggests that the stability of the bonding to these new phases is stronger than to schwertmannite but further research is required to fully understand the fate of schwertmannite bound As(III) upon transformation to new minerals of higher stability, potentially higher affinity but also reduced specific surface area or particular relevance will be the understanding of the impact of fluctuating redox conditions on the long term stability of solid-phase bound As. Release of sulfate during dissolution of schwertmannite may trigger sulfate reduction under reducing conditions and may open up evolution pathways for the formation of secondary iron sulfide phases. 


\section{ACKNOWLEDGEMENT}

The work was supported by the German Academic Exchange Service (DAAD) and the Geotechnologien programme (BMBF, No-03G0714A). Dr. Janneck (GEOS, Freiburg) is acknowledged to provide the SHM sample. C. S. acknowledges a joint postdoctoral appointment at the Universities of Bayreuth and Tübingen funded through the DFG research unit FOR 580 - electron transfer processes in anoxic aquifers (e-TraP). We are grateful for the fruitful comments of three anonymous reviewers.

\section{REFERENCES}

Bigham J. M., Carlson L., Murad E. (1994) Schwertmannite, a new iron oxyhydroxysulfate from pyhäsalmi, Finland, and other localities. Mineral. Mag.. 58, 641-648.

Bigham J. M., Schwertmann U., Carlson L. and Murad E. (1990) A poorly crystallized oxyhydroxysulfate of iron formed by bacterial oxidation of Fe (II) in aid mine waters. Geochem. Cosmochim. Acta 54. 2743-2758.

Bigham J. M., Schwertmann U., Traina S. J., Winland R. L. and Wolf M. (1996) Schwertmannite and the chemical modeling of iron in acid sulfate waters. Geochim. Cosmochim. Acta 60, 2111-2121.

Burke S. and Banwart S. (2000) The effects of pH on surface-catalysed oxidation of aqueous Fe(II). J. Conf. Abs. 5, 267.

Burton E. D. and Johnston S.G. (2012) Impact of silica on the reductive transformation of schwertmannite and the mobilization of arsenic. Geochim. Cosmochim. Acta 96, 135153.

Burton E. D., Bush R. T., Johnston S. G. Watling K. M., Hocking R. K., Sullivan L. A. and Parker, G.K. (2009) Sorption of arsenic(V) and arsenic(III) to schwertmannite. Environ. Sci. Technol. 43, 9202-9207. 
Burton E. D., Bush R. T., Sullivan L. A. and Mitchell D. R. G. (2007) Reductive transformation of iron and sulfur in schwertmannite-rich accumulations associated with acidified coastal lowlands. Geochim. Cosmochim. Acta 71, 4456-4473.

Burton E. D., Bush R. T., Sullivan L. A. and Mitchell D. R. G. (2008) Schwertmannite transformation to goethite via the $\mathrm{Fe}(\mathrm{II})$ pathway: reaction rates and implications for iron-sulfide formation. Geochim. Cosmochim. Acta 72, 4551-4564.

Burton E. D., Johnston S. G., Watling K., Bush R. T., Keene A. F. and Sullivan L. A. (2010) Arsenic effects and behavior in association with the Fe(II)-catalyzed transformation of schwertmannite. Environ. Sci. Technol. 44, 2016-2021.

Caraballo M. A., Rimstidt J. D., Macías F., Nieto J. M. and Hochella M. F. Jr. (2013) Metastability, nanocrystallinity and pseudo-solid solution effects on the understanding of schwertmannite solubility. Chem. Geol. 360-361, 22-31.

Carlson L., Bigham J. M., Schwertmann, U., Kyek, A. and Wagner F. (2002) Scavenging of As from acid mine drainage by schwertmannite and ferrihydrite: A comparison with synthetic analogues. Environ. Sci. Technol. 36, 1712-1719.

Casiot C., Lebrun, S., Morin, G., Bruneel, O., Personne, J.C. and Elbaz-Poulichet, F. (2005) Sorption and redox processes controlling arsenic fate and transport in a stream impacted by acid mine drainage. Sci. Total Environ. 347, 122- 130.

Catalano J. G., Luo Y. and Otemuyiwa B. (2011) Effect of aqueous Fe(II) on arsenate sorption on goethite and hematite. Environ. Sci. Technol. 45, 8826-8833.

Collins R.N., Jones A. M. and Waite, T. D. (2010) Schwertmannite stability in acidified coastal environments. Geochim. Cosmochim. Acta 74, 482-496.

Cornell R. M. and Schwertmann U. (2003) The Iron Oxides, Structure, Properties, Reactions, Occurrences and Uses. Wiley-VCH Gmbh \& Co. KGaA, Weinheim, Germany. 
De Grave E., Barrero C. A., Da Costa G. M., Vandenberghe R. E. and Van San E. (2002) Mössbauer spectra of $\alpha$ - and $\gamma$-polymorphs of $\mathrm{FeOOH}$ and $\mathrm{Fe}_{2} \mathrm{O}_{3}$ : effects of poor crystallinity and of Al-for-Fe substitution. Clay Miner. 37, 591-606.

Dixit S. and Hering J. G. (2003) Comparison of arsenic(V) and arsenic(III) sorption onto iron oxide minerals: implications for arsenic mobility. Environ. Sci. Technol. 37, 4182-4189.

Dixit S. and Hering J. G. (2006) Sorption of Fe(II) and As(III) on goethite in single- and dualsorbate systems. Chem. Geol. 228, 6-15.

Doelsch E., Rose J., Masion A., Bottero J. Y., Nohon D. and Bertsch P. M. (2000) Speciation and crystal chemistry of iron(III) chloride hydrolysed in the presence of $\mathrm{SiO}_{4}$ ligands. An Fe K-edge EXAFS study. Langmuir 16, 4726-4731.

Dzombak D.A. and Morel F.M.M. (1990) Surface Complexation Modeling-Hydrous Ferric Oxide. Wiley-Interscience, New York.

Egal M., Casiot C., Morin G., Parmentier M., Bruneel O., Lebrun S. and Elbaz-Poulichet F. (2009) Kinetic control on the formation of tooeleite, schwertmannite and jarosite by Acidithiobacillus ferrooxidans strains in an As(III)-rich acid mine water. Chem. Geol. 265, 432-441.

French R.A., Caraballo M.A., Kim B., Rimstidt J.D., Murayama M. and Hochella Jr. M.F. (2012) The enigmatic iron oxyhydroxysulfate nanomineral schwertmannite: morphology, structure and composition. Ame. Mineral. 97, 1469-1482.

Fukushi K., Sasaki M., Sato T., Yanase N., Amano H. and Ikeda H. (2003) A natural attenuation of arsenic in drainage from an abandoned arsenic mine dump. Appl. Geochem. 18, 1267-1278.

Fukushi K., Sato, T. and Yanase, N. (2004) Arsenate sorption on schwertmannite. Ame. Mineral. 89, 1728-1734. 
Glombitza F., Janneck E., Arnold I., Rolland W. and Uhlmann W. (2007) Eisenhydroxisulfate aus der Bergbauwasserbehandlung als Rohstoff. In Heft 110 der Schriftenreihe der GDMB, S. 31-40 ISBN 3-935797-35-4.

Handler R. M., Beard, Brian L., Johnson C. M. And Scherer M. M. (2009) Atom exchange between aqueous Fe(II) and goethite: An Fe isotope tracer study. Environ. Sci. Technol. 43, $1102-1107$.

Hansel C., Benner S. and Fendorf S. (2005) Competing Fe(II)-Induced mineralization pathways of ferrihydrite. Environ. Sci. Technol. 39, 7147-7153.

Janneck E., Burghardt, D., Martin M., Damian C.H., Schöne G., Meyer, J. and Peiffer S. (2011) From waste to valuable substance: Utilization of schwertmannite and lignite filter ash for removal of arsenic and uranium from mine drainage. Proc. Inter. Mine Water Assoc. 2011, Aachen, Germany.

Jones A. M., Collins R. N., Rose, J. and Waite, T. D. (2009) The effect of silica and natural organic matter on the Fe(II)-catalyzed transformation and reactivity of Fe(III) minerals. Geochim. Cosmochim. Acta 73, 4409-4422.

Jönsson J., Jönsson J. and Lovgren L. (2006) Precipitation of secondary Fe(III) minerals from acid mine drainage. Appl. Geochem. 21, 437-445.

Jönsson J., Persson P., Sjöberg S. and Lovgren L. (2005) Schwertmannite precipitated from acid mine drainage: phase transformation, sulphate release and surface properties. Appl. Geochem. 20, 179-191.

Larese-Casanova P. and Scherer M. M. (2007) Fe(II) sorption on hematite: new insights based on spectroscopic measurements. Environ. Sci. Technol. 41, 471-477.

Liao Y., Liang J. and Zhou L. (2011) Adsorptive removal of As(III) by biogenic schwertmannite from simulated As-contaminated groundwater. Chemosphere 83, 295301. 
Liu H. Guo H., Li, P. and Wei Y. (2008) The transformation of ferrihydrite in the presence of trace Fe(II): The effect of the anionic media. J. Solid State Chem. 181, 2666-2671.

Liu H., Guo H., Li P. and Wei Y. (2009) Transformation from $\delta$-FeOOH to hematite in the presence of trace Fe(II). J. Phys. Chem. Solids 70, 186-191.

Liu H., Wei Y. and Sun Y. (2005) The formation of hematite from ferrihydrite using Fe(II) as a catalyst. J. Mol. Catal. A: Chem. 226, 135-140.

Majzlan J. and Myneni S.C.B. (2005) Speciation of iron and sulfate in acid waters: Aqueous clusters to mineral precipitates. Environ. Sci. Technol. 39, 188-194.

Morin G., Juillot F., Casiot C., Bruneel O., Personné J., Elbaz-Poulichet F., Leblang M., Ildefonse P. and Calas G. (2003) Bacterial formation of tooeleite and mixed arsenic(III) or arsenic(V)-iron(III) gels in the Carnoule`s acid mine drainage, France. A XANES, XRD, and SEM study. Environ. Sci. Technol. 37, 1705-1712.

Mukiibi M. Ela, W. P. and Sáez A. E. (2008) Effect of ferrous iron on arsenate sorption to amorphous ferric hydroxide. Ann. N.Y. Acad. Sci. 1140, 335-345.

Paikaray S. and Peiffer S. (2010) Dissolution kinetics of sulfate from schwertmannite under variable pH conditions. Mine Wat. Environ. 29, 263-269.

Paikaray S. and Peiffer S. (2012) Abiotic schwertmannite transformation kinetics and role of sorbed As(III). Appl. Geochem. 27, 590-597.

Paikaray S., Göttlicher J. and Peiffer S. (2011) Removal of As(III) from acidic waters using schwertmannite: Surface speciation and effect of synthesis pathway. Chem. Geol. 283, 134-142.

Paikaray S., Göttlicher J. and Peiffer S. (2012) As(III) retention kinetics, equilibrium and redox stability on biosynthesized schwertmannite and its fate and control on schwertmannite stability on acidic ( $\mathrm{pH} 3.0)$ aqueous exposure. Chemosphere 86, 557564. 
Paikaray S., Essilfie-Dughan J., Göttlicher J., Pollock K. and Peiffer, S. (2014) Redox Stability of As(III) on Schwertmannite Surfaces. J. Hazard. Mater. 265, 208-216.

Pedersen H.D., Postma D., and Jakobsen R. (2006) Release of arsenic associated with the reduction and transformation of iron oxides. Geochim. Cosmochim Acta 70, 4116-4129.

Peine A., Tritschler A., Küsel K. and Peiffer S. (2000) Electron flow in an iron-rich acidic sediment - evidence for an acidity-driven iron cycle. Limnol. Oceanogr. 45, 1077-1087.

Peretyazhko T., Zachara J. M., Boily J. F., Xia Y., Gassman P. L., Arey B. W. and Burgos W. D. (2009) Mineralogical transformations controlling acid mine drainage chemistry. Chem. Geol. 262, 169-178.

Regenspurg S. and Peiffer S. (2005) Arsenate and chromate incorporation in schwertmannite. Appl. Geochem. 20, 1226-1239.

Regenspurg S., Andreas B. and Peiffer S. (2004) Formation and stability of schwertmannite in acidic mining lakes. Geochim. Cosmochim. Acta 68, 1185-1197.

Rose S. and Elliot W. C. (2000) The effects of pH regulation upon the release of sulfate from ferric precipitates formed in acid mine drainage. Appl. Geochem. 15, 27-34.

Schwertmann U. and Carlson L. (2005) The pH-dependent transformation of schwertmannite to goethite at $25^{\circ} \mathrm{C}$. Clay Minerals 40, 63-66.

Schwertmann U. and Cornell R. M. (1991) Iron Oxides in the Laboratory - Preparation and Characterization. VCH Verlagsgesellschaft mbH, Weinheim, Germany.

Tabatabai M. A. (1974) A rapid method for determination of sulfate in water samples. Environ. Let. 7, 237-243.

Tamura H., Goto K., Yotsuyanagi T. and Nagayama G. (1974) Spectrophotometric determination of iron(II) with 1, 10-phenanthroline in the presence of large amounts of iron(III). Talanta 21, 314-318.

Tronc E., Belleville P., Jolivet J. P. and Livage J. (1992) Transformation of ferric hydroxide into spinel by Fe(II) adsorption. Langmuir 8, 313-319. 
Webster J. G., Swedlund P. J. and Webster K. S. (1998) Trace metal adsorption onto an acid mine drainage iron(III) oxyhydroxysulfate. Environ. Sci. Technol. 32, 1361-1368.

Williams A. G. B. and Scherer M. M. (2004) Spectroscopic evidence for Fe(II)-Fe(III) electron transfer at the iron oxide-water interface. Environ. Sci. Technol. 38, 47824790.

Winland R. L., Traina S. J. and Bigham J. M. (1991) Chemical composition of ochreous precipitates from Ohio coal mine drainage. J. Environ. Qual. 20, 452-460.

\section{Figure Captions}

Fig. 1. X-ray diffractograms (A), Fourier Transform IR spectra (B), scanning electron microscopic images (C and D) of schwertmannite with no sorbed As(III) and 0.92 wt \% sorbed As(III) through 5 days (continuous mixed batch reactor (CMBR) process. The SHM and SHM-As in (A), (B), (C) and (D) denotes schwertmannite with no sorbed As(III) and 0.92 wt \% sorbed As(III), respectively. The y-axis in (A) represents intensity, while in (B) represents transmission.

Fig. 2. (A) Fourrier transform IR spectra of transformed products after $202 \mathrm{~h}$ in the presence of $1 \mathrm{mM} \mathrm{Fe}(\mathrm{II})_{\mathrm{aq}}$ of schwertmannite with no sorbed $\mathrm{As}(\mathrm{III})$ at different $\mathrm{pH}$ (bottom) and schwertmannite with $0.92 \mathrm{wt} \%$ sorbed As(III) (top). The y-axis represents transmission. (B) X-ray diffractograms of transformed products of As(III) loaded (0.92 wt \%) (top) and pure schwertmannite (bottom) after $202 \mathrm{~h}$ at pH 5, 6 and 6.9 in presence of I mM Fe(II) aq. The original diffractograms are shown at the bottom for comparison. The y-axis represents intensity. G represents goethite while L represents lepidocrocite.

Fig. 3. Scanning electron microscopy images of transformed products formed from schwertmannite with no sorbed As(III) (left) and with sorbed (0.92 wt \%) As(III) (right) after $202 \mathrm{~h}$ ageing in the presence of $1 \mathrm{mM} \mathrm{Fe}(\mathrm{II})_{\mathrm{aq}}$ at $\mathrm{pH} 5$ (top), $\mathrm{pH} 6$ (middle) and $\mathrm{pH}$ 6.9 (bottom). Note the difference in scale between pH 5-6 vs. $\mathrm{pH} 7$. 
Fig. 4. Mössbauer spectra obtained at $\sim 5 \mathrm{~K}$ from schwertmannite (SHM) and schwertmannite with (0.92 wt\%) sorbed (As(III) (SHM-As), and from samples after $202 \mathrm{~h}$ ageing at $\mathrm{pH} 6$ and 6.9, respectively in the presence of $1 \mathrm{mM} \mathrm{Fe}(\mathrm{II})_{\mathrm{aq}}$. Open circles are the measured data, the solid black line represents the overall fit to the data. Individual subspectra are schwertmannite (dark grey), lepidocrocite (grey) and goethite (light grey).

Fig. 5. Mössbauer spectra obtained at room temperature from SHM and SHM-As and their corresponding transformed products after $202 \mathrm{~h}$ ageing at $\mathrm{pH} 6$ and 6.9, respectively in presence of $1 \mathrm{mM} \mathrm{Fe}(\mathrm{II})_{\mathrm{aq}}$. At room temperature, paramagnetic doublets for schwertmannite and lepidocrocite as well as superparamagnetic goethite strongly overlap and therefore no attempt was made to model them as individual phases. The grey doublet represents all (super) paramagnetic mineral phases; the light grey sextet is goethite. The spectra are zoomed in to highlight the goethite sextet contribution. Full spectra are shown in supplementary Fig. 6.

Fig. 6. Release of sulfate upon ageing of SHM (marked as $1 \mathrm{mM}$ ) and SHM-As (marked as 1 mM_As) in the absence $(0 \mathrm{mM})$ and presence $(1 \mathrm{mM})$ of $\mathrm{Fe}(\mathrm{II})_{\mathrm{aq}}$ at $\mathrm{pH} 5(\mathrm{~A}), \mathrm{pH} 6$ (B) and pH 6.9 (C).

Fig. 7. Concentration of residual dissolved $\mathrm{Fe}(\mathrm{II})_{\mathrm{aq}}$ at different times of ageing in the presence of SHM (marked as $1 \mathrm{mM}$ ) and SHM-As (marked as $1 \mathrm{mM} \_$As) after addition of $1 \mathrm{mM}$ $\mathrm{Fe}(\mathrm{II})_{\mathrm{aq}}$ at $\mathrm{pH} 5(\mathrm{~A}), \mathrm{pH} 6(\mathrm{~B})$ and $\mathrm{pH} 6.9(\mathrm{C})$.

Fig. 8. Release of As from SHM-As in the absence $(0 \mathrm{mM})$ and presence of $1 \mathrm{mM} \mathrm{Fe}(\mathrm{II})_{\mathrm{aq}}$ at pH 5 (A), pH 6 (B) and pH 6.9 (C) for different times of ageing.

Table 1. Physical and Chemical Properties of Schwertmannites with (SHM-As) and without (SHM) Adsorbed As(III) and Transformation Products in Presence of $1 \mathrm{mM}$ $\mathrm{Fe}(\mathrm{II})_{\mathrm{aq}}$

\begin{tabular}{ccccccc}
\hline Samples & $\begin{array}{c}\mathbf{F e}_{\text {tot }} / \mathbf{S}_{\text {tot }} \\
\text { ratio }\end{array}$ & $\begin{array}{c}\text { SSA } \\
\left(\mathrm{m}^{2} / \mathbf{g}\right)\end{array}$ & $\begin{array}{c}\mathbf{A s}(\mathrm{III}) \\
(\mathbf{w t} \%)\end{array}$ & Chemical Formula & \multicolumn{2}{c}{$\begin{array}{c}\text { Transformation } \\
\text { Products* }\end{array}$} \\
\hline & & & & $\underline{\mathrm{pH} 5}$ & $\underline{\mathrm{pH} 6} \quad \underline{\mathrm{pH} \mathrm{6.9}}$ \\
\hline
\end{tabular}




\begin{tabular}{cccccccc}
\hline SHM & 6.3 & 14.7 & 0 & $\mathrm{Fe}_{8} \mathrm{O}_{8}(\mathrm{OH})_{4.64}\left(\mathrm{SO}_{4}\right)_{1.68}$ & - & $\mathrm{L}>\mathrm{G}$ & $\mathrm{L}>\mathrm{G}$ \\
SHM-As & 6.4 & 17.1 & 0.92 & $\mathrm{Fe}_{8} \mathrm{O}_{8}(\mathrm{OH})_{4.82}\left(\mathrm{SO}_{4}\right)_{1.59}$ & - & $\mathrm{L}$ & $\mathrm{L}>\mathrm{G}$ \\
\hline
\end{tabular}

*S=schwertmannite, L=lepidocrocite, $\mathrm{G}=$ goethite

Table 2. Mössbauer Parameters Used in Fitting Models for 5 K Spectra.

\begin{tabular}{|c|c|c|c|c|c|c|}
\hline Mineral & $\begin{array}{c}\delta^{\mathrm{a}} \\
(\mathrm{mm} / \mathrm{s})\end{array}$ & $\begin{array}{c}\Delta \mathrm{E}_{\mathrm{Q}}^{\mathrm{b}} \\
(\mathrm{mm} / \mathrm{s})\end{array}$ & $\begin{array}{l}\mathrm{B}_{\mathrm{hf}}^{\mathrm{c}} \\
(\mathrm{T})\end{array}$ & $\begin{array}{l}\sigma_{B}{ }^{d} \\
(T)\end{array}$ & $\begin{array}{c}\text { Lorentzian } \\
\text { HWHM }^{\mathrm{e}} \\
(\mathrm{mm} / \mathrm{s})\end{array}$ & $\begin{array}{l}\text { Area }^{\mathrm{f}} \\
(\%)\end{array}$ \\
\hline \multicolumn{7}{|c|}{ Pure Schwertmannite (SHM) } \\
\hline SHM & 0.50 & -0.22 & 45.2 & 1.9 & 0.24 & 100 \\
\hline \multicolumn{7}{|c|}{ Pure Schwertmannite + As (SHM-As) } \\
\hline SHM-As & 0.49 & -0.20 & 45.2 & 1.9 & 0.23 & 100 \\
\hline \multicolumn{7}{|c|}{ SHM aged for 202 hours at pH 6.0} \\
\hline SHM & {$[0.50]^{\mathrm{g}}$} & {$[-0.22]$} & [45.2] & [1.9] & {$[0.24]$} & 16 \\
\hline Lepidocrocite & 0.48 & -0.05 & 45.7 & [2] & & 45 \\
\hline Goethite & 0.50 & -0.09 & 49.0 & {$[2]$} & & 39 \\
\hline \multicolumn{7}{|c|}{ SHM-As aged for 202 hours at pH 6.0} \\
\hline SHM-As & {$[0.49]$} & {$[-0.20]$} & [45.2] & [1.9] & {$[0.23]$} & 10 \\
\hline Lepidocrocite & 0.48 & -0.06 & 45.6 & {$[2]$} & & 66 \\
\hline Goethite & 0.50 & -0.09 & 49.0 & {$[2]$} & & 24 \\
\hline \multicolumn{7}{|c|}{ SHM aged for 202 hours at pH 6.9} \\
\hline SHM & {$[0.50]$} & {$[-0.22]$} & [45.2] & [1.9] & {$[0.24]$} & 0 \\
\hline Lepidocrocite & 0.48 & -0.05 & 45.6 & {$[2]$} & & 61 \\
\hline Goethite & 0.49 & -0.09 & 48.9 & {$[2]$} & & 39 \\
\hline \multicolumn{7}{|c|}{ SHM-As aged for 202 hours at pH 6.9} \\
\hline SHM-As & {$[0.49]$} & {$[-0.20]$} & [45.2] & [1.9] & {$[0.23]$} & 0 \\
\hline Lepidocrocite & 0.48 & -0.06 & 45.5 & {$[2]$} & & 61 \\
\hline Goethite & 0.50 & -0.06 & 48.6 & [2] & & 39 \\
\hline
\end{tabular}

${ }^{\mathrm{a}}$ Isomer or center shift.

${ }^{\mathrm{b}}$ Quadrupole splitting.

${ }^{\mathrm{c}}$ Internal magnetic field.

${ }^{\mathrm{d}}$ Standard deviation of hyperfine field distribution.

${ }^{\mathrm{e}}$ Half Width Half Maximum of Lorentzian lineshape (global parameter).

${ }^{\mathrm{f}}$ Subspectral area ratio.

${ }^{\mathrm{g}}$ Values in square brackets were not allowed to vary during the fitting process. 
Table 3. Mössbauer Parameters Used in Fitting Models for Room Temperature Spectra.

\begin{tabular}{|c|c|c|c|c|c|c|}
\hline Mineral & $\begin{array}{c}\delta^{\mathrm{a}} \\
(\mathrm{mm} / \mathrm{s})\end{array}$ & $\begin{array}{c}\Delta \mathrm{E}_{\mathrm{Q}}^{\mathrm{b}} \\
(\mathrm{mm} / \mathrm{s})\end{array}$ & $\begin{array}{l}\mathrm{B}_{\mathrm{hf}}^{\mathrm{c}} \\
(\mathrm{T})\end{array}$ & $\begin{array}{c}\sigma_{\mathrm{B}}^{\mathrm{d}} \text { or } \sigma_{\Delta} \\
(\mathrm{T}) \text { or } \\
(\mathrm{mm} / \mathrm{s})\end{array}$ & $\begin{array}{c}\text { Lorentzian } \\
\mathrm{HWHM}^{\mathrm{e}} \\
(\mathrm{mm} / \mathrm{s})\end{array}$ & $\begin{array}{l}\text { Area }^{f} \\
(\%)\end{array}$ \\
\hline \multicolumn{7}{|c|}{ Pure Schwertmannite (SHM) } \\
\hline Paramagnetic SHM & 0.38 & 0.70 & - & 0.17 & 0.16 & 100 \\
\hline \multicolumn{7}{|c|}{ Pure Schwertmannite + As (SHM-As) } \\
\hline Paramagnetic SHM- & 0.38 & 0.72 & - & 0.17 & 0.16 & 100 \\
\hline \multicolumn{7}{|c|}{ SHM aged for 202 hours at $p H 6.0$} \\
\hline $\begin{array}{l}\text { (super)paramagnetic } \\
\text { phases }\end{array}$ & 0.37 & 0.73 & - & 0.21 & 0.17 & 92 \\
\hline Goethite & 0.32 & -0.11 & 31.5 & 4.9 & & 8 \\
\hline \multicolumn{7}{|c|}{ SHM-As aged for 202 hours at pH 6.0} \\
\hline (super)paramagnetic & 0.37 & 0.73 & - & 0.21 & 0.17 & 100 \\
\hline \multicolumn{7}{|c|}{ SHM aged for 202 hours at $p H 6.9$} \\
\hline $\begin{array}{l}\text { (super)paramagnetic } \\
\text { phases }\end{array}$ & 0.37 & 0.71 & - & 0.21 & 0.18 & 94 \\
\hline Goethite & 0.35 & -0.02 & 30.5 & 4.6 & & 6 \\
\hline \multicolumn{7}{|c|}{ SHM-As aged for 202 hours at pH 6.9} \\
\hline $\begin{array}{l}\text { (super)paramagnetic } \\
\text { phases }\end{array}$ & 0.37 & 0.73 & - & 0.22 & 0.18 & 100 \\
\hline \multicolumn{7}{|c|}{$\begin{array}{l}\text { } \\
\text { asomer or center shift. } \\
{ }^{b} \text { Quadrupole splitting. } \\
\text { c Internal magnetic field. } \\
{ }^{d} \text { Standard deviation of hyperfine field distribution or quadrupole splitting distribution. } \\
\text { e Half Width Half Maximum of Lorentzian lineshape (global parameter). } \\
{ }^{\text {f }} \text { Subspectral area ratio. }\end{array}$} \\
\hline
\end{tabular}



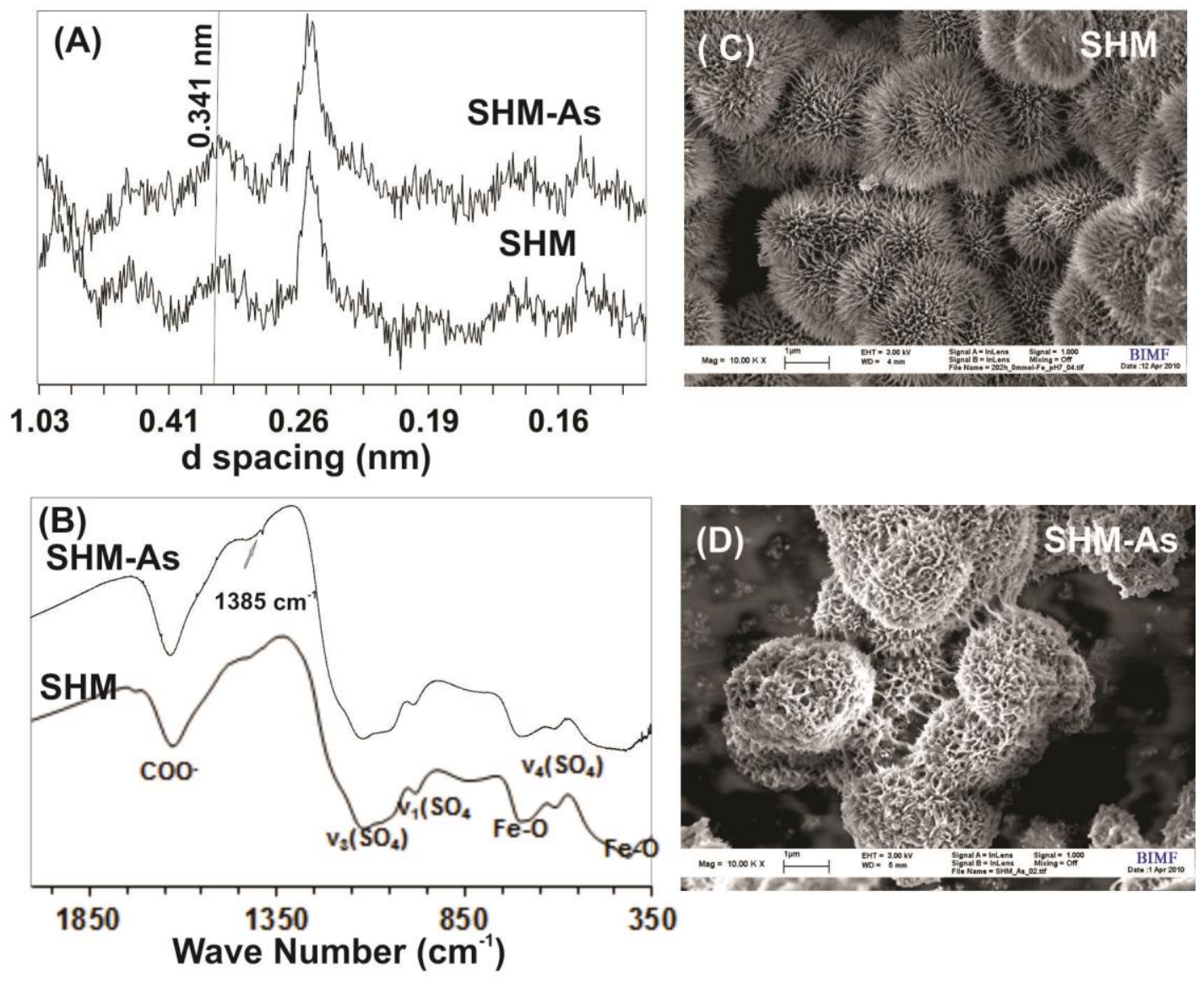

Fig. 1 
(A)
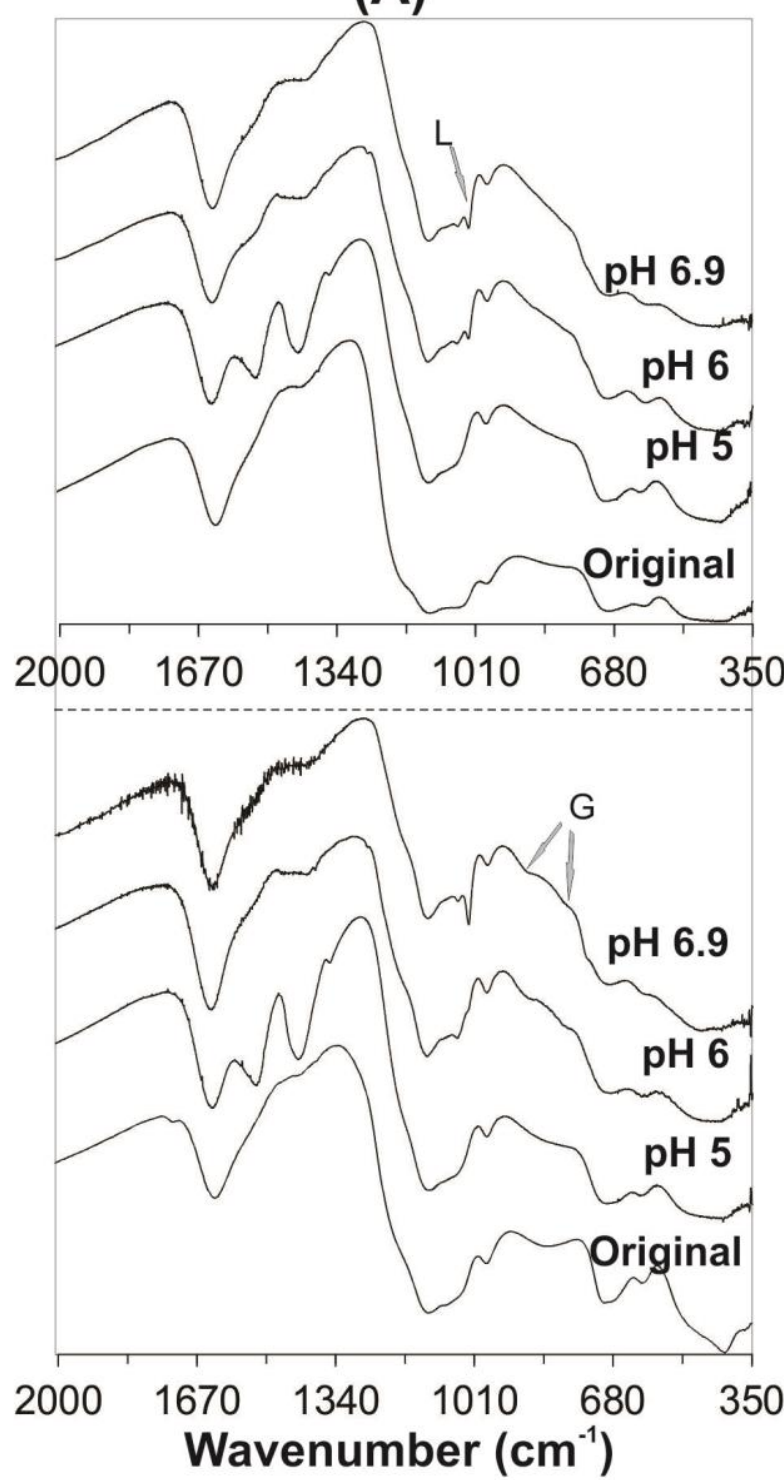

(B)
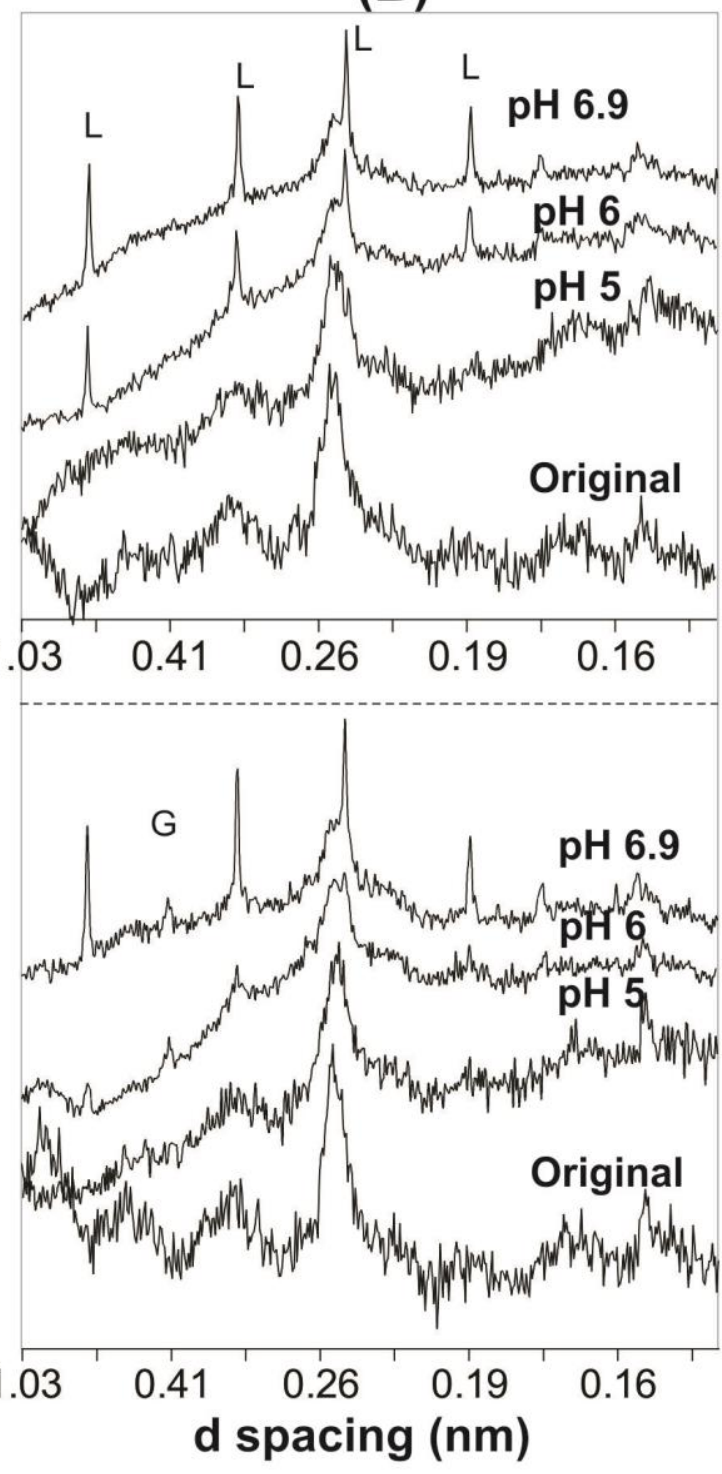

Fig. 2 
SHM

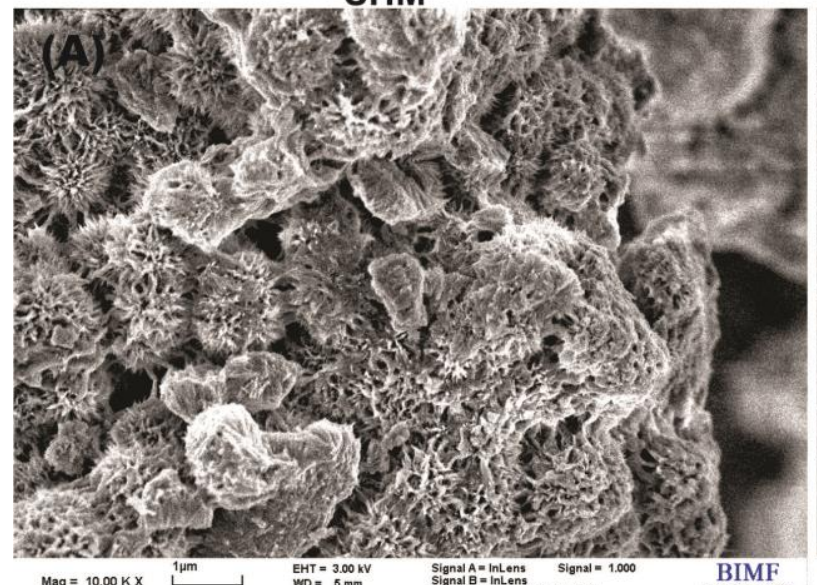

\section{SHM-As}

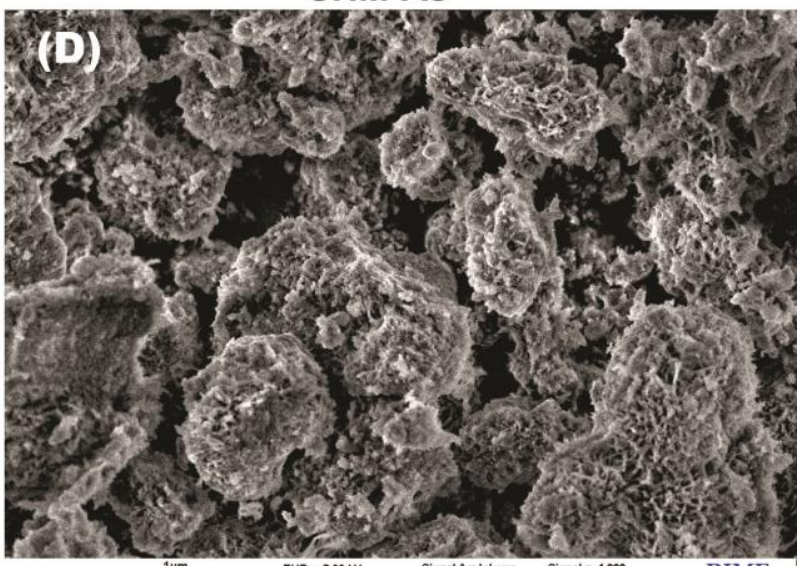

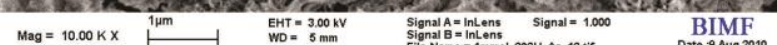
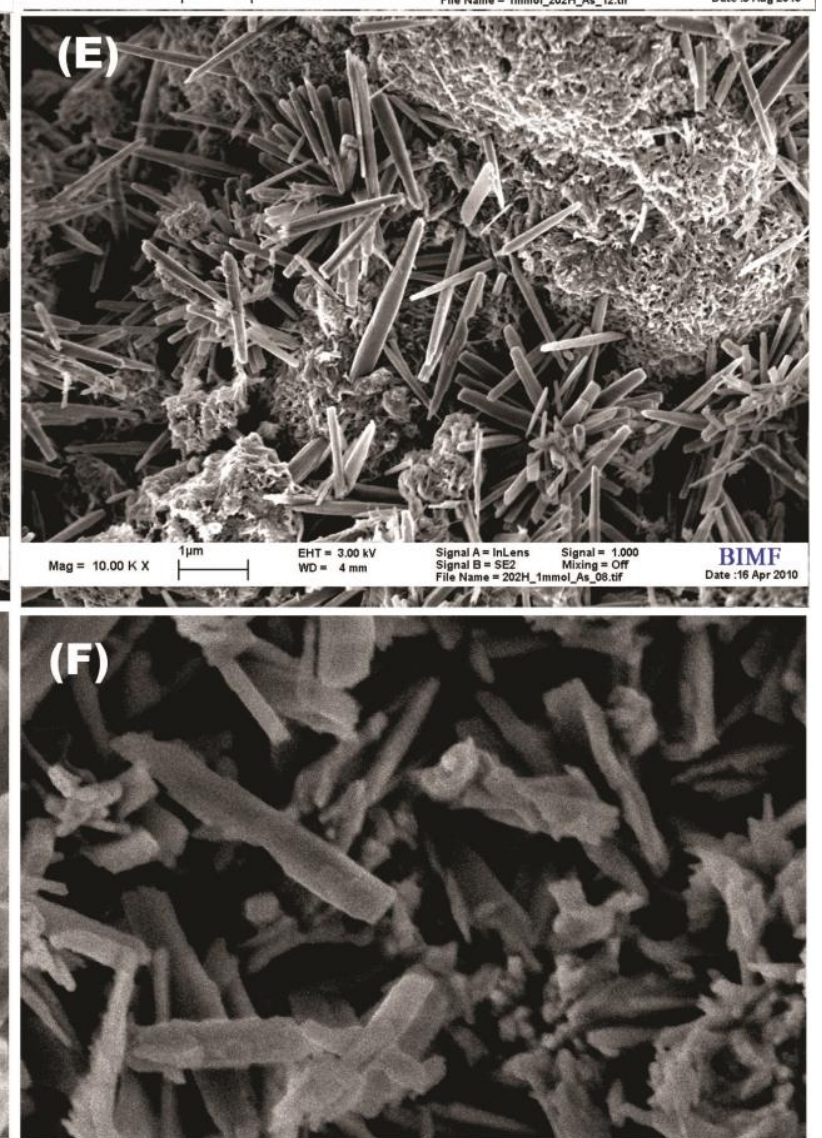

$\mathrm{Mag}=50.00 \mathrm{KX}$

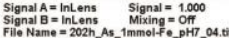

$\underset{\text { Date :12:Apr } 2010}{\text { BIMF }}$

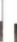

Fig. 3 

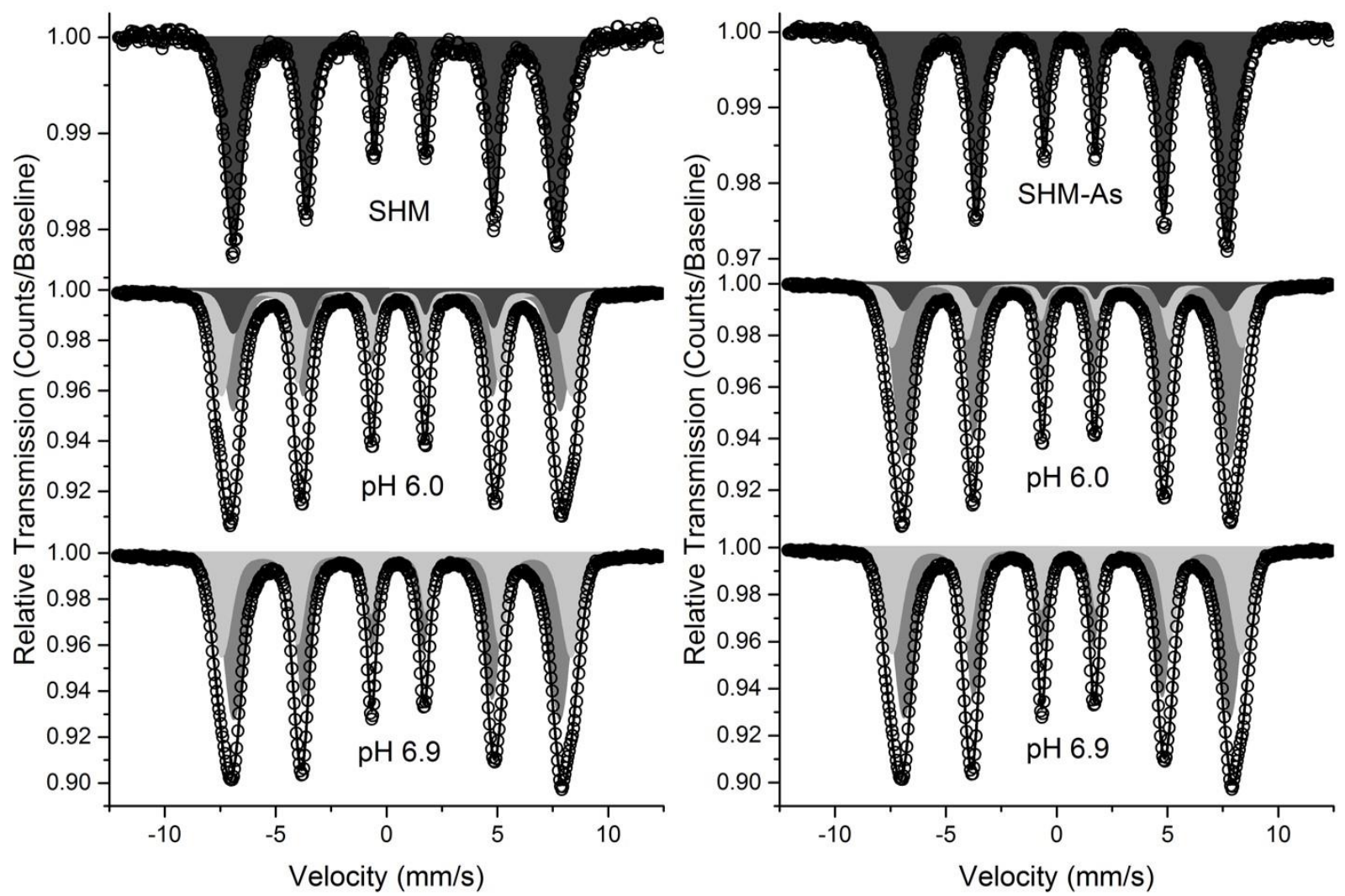

Fig. 4
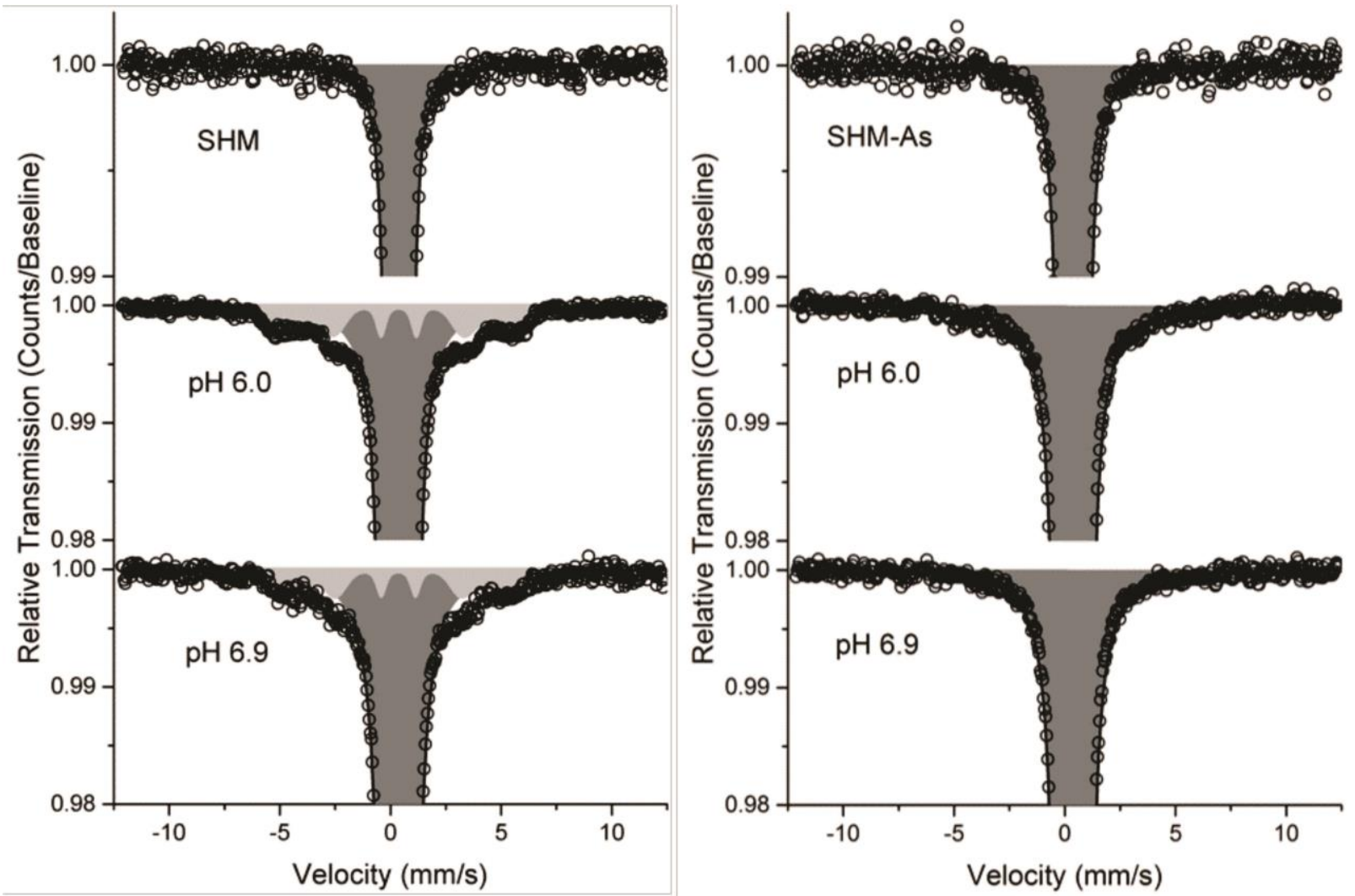

Fig. 5 

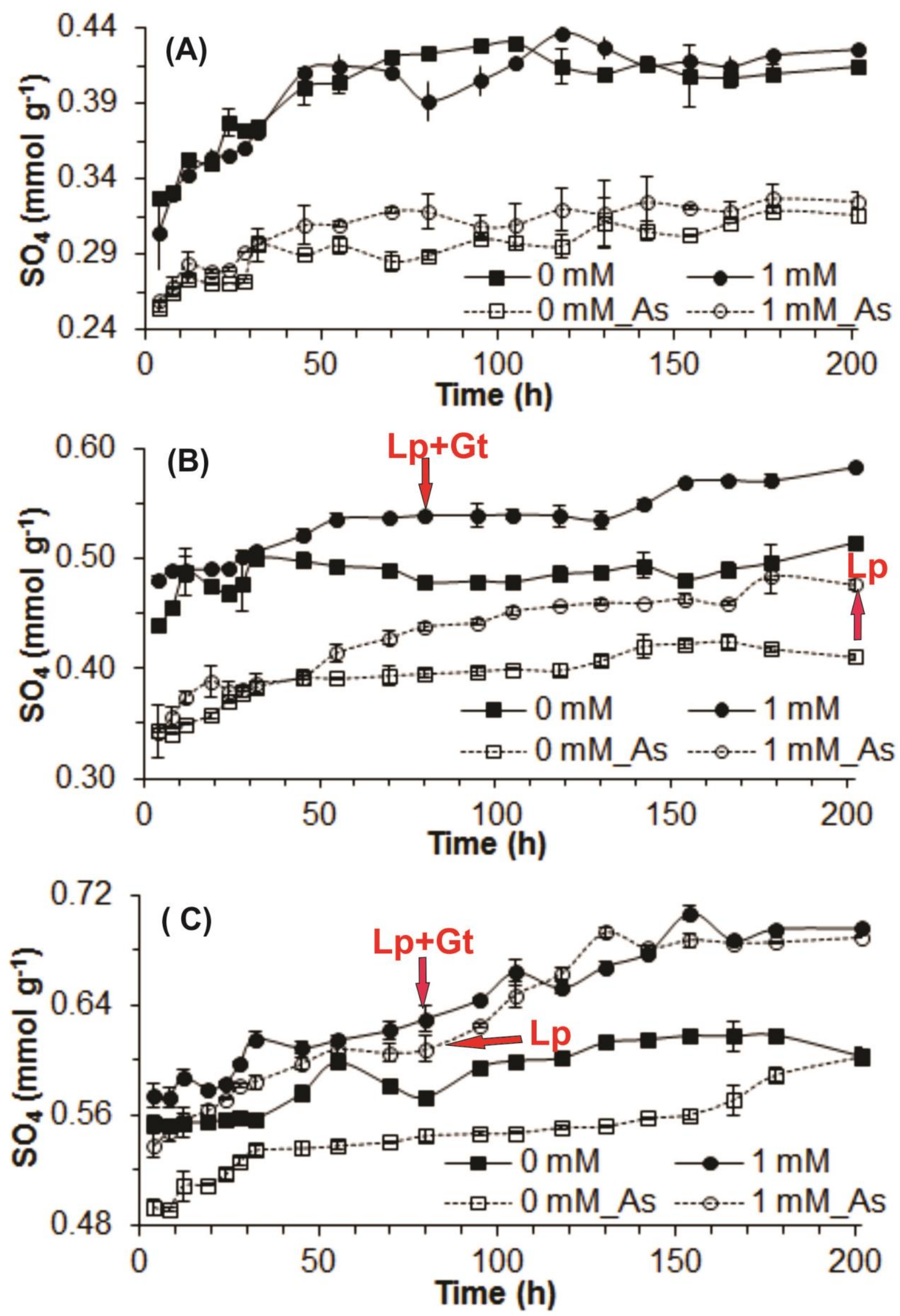

Fig. 6 

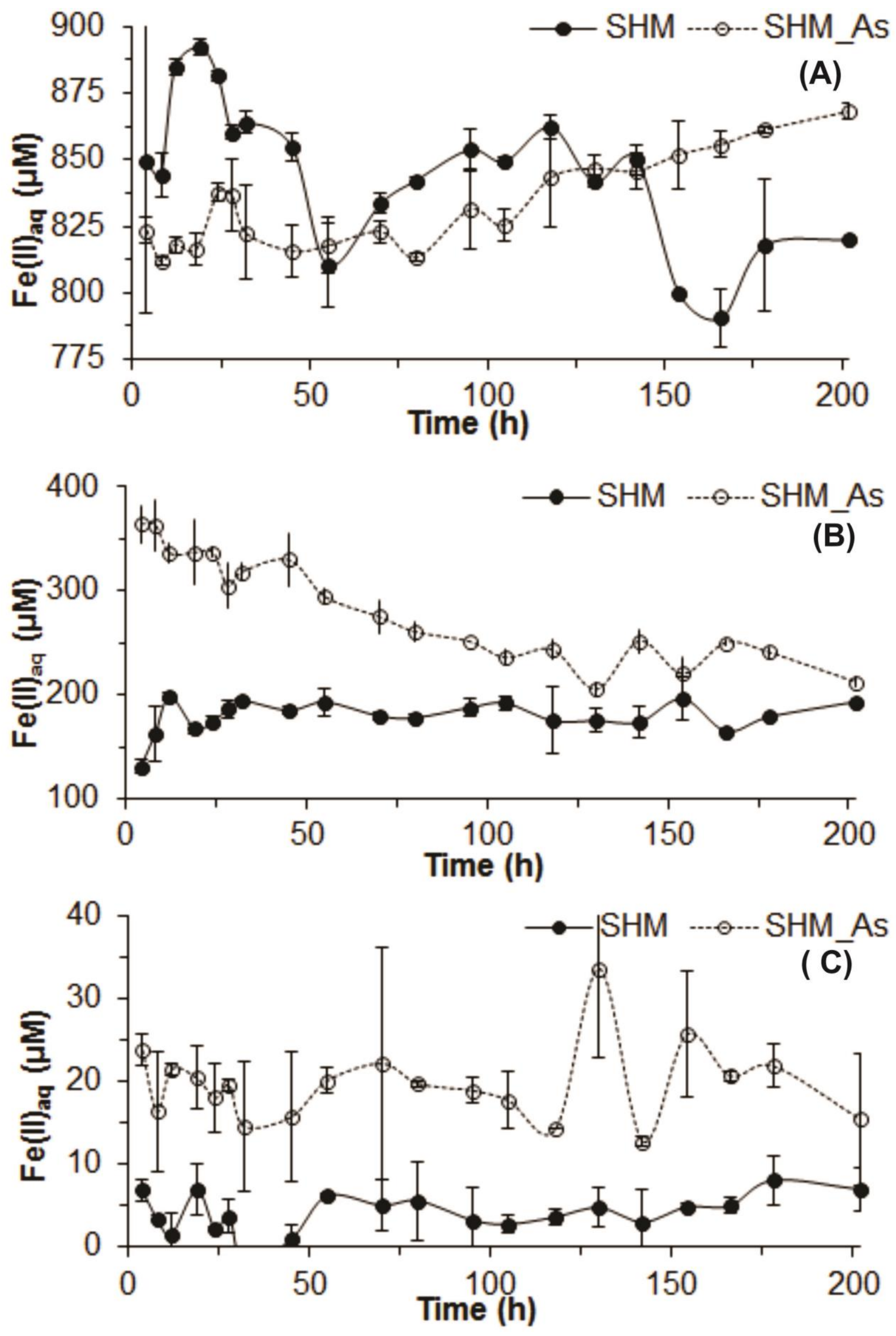

Fig. 7 

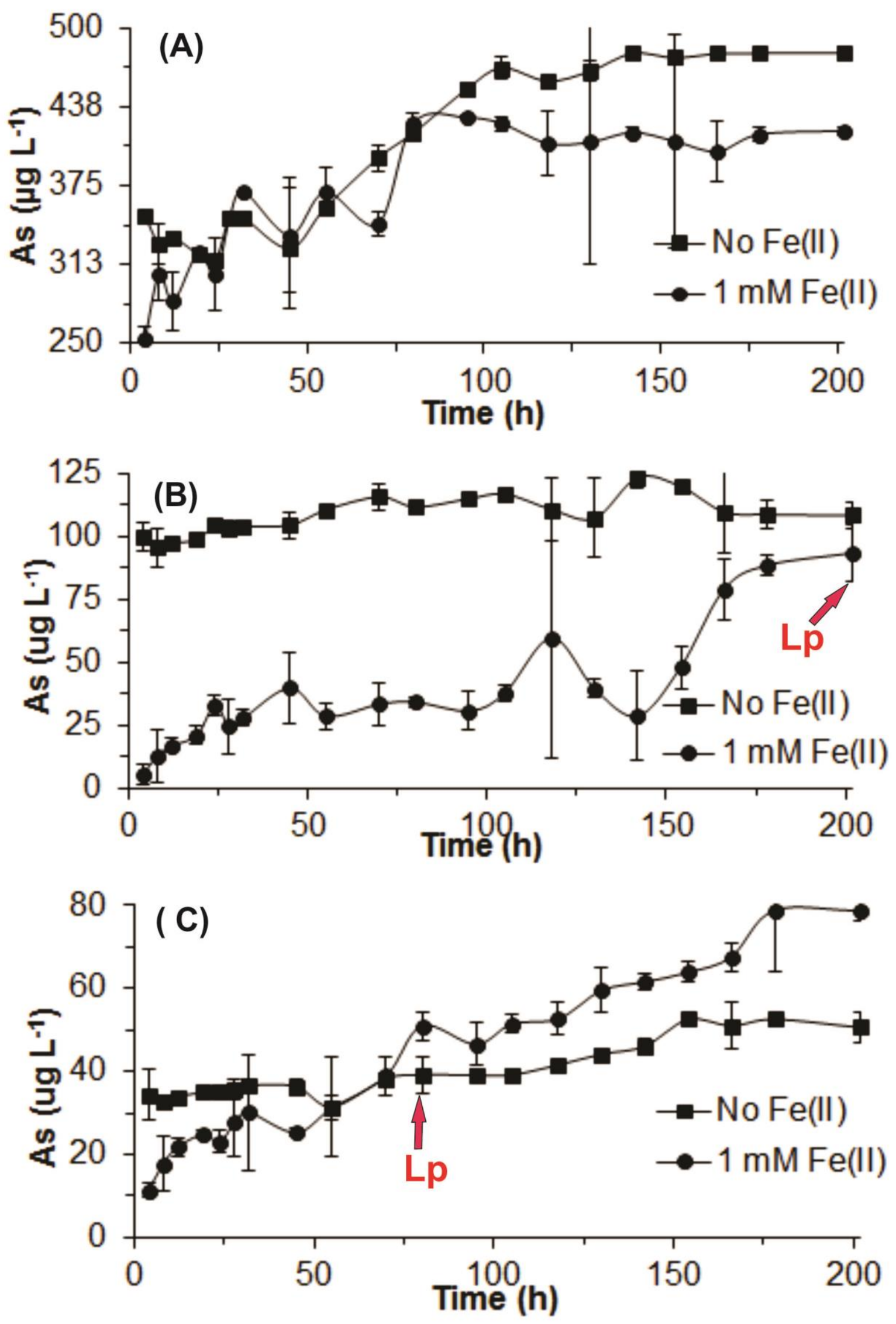

Fig. 8 


\section{Appendix 1 \\ Supplementary Information \\ Schwertmannite stability in anoxic Fe(II)-rich aqueous solution}

\section{Figure Captions}

Paikaray et al., 2017

Fig. 1. X-ray diffractograms of transformed products of schwertmannite with unadsorbed As(III) and 0.92 wt \% adsorbed As(III) (marked as ...As) at pH 5, 6 and 6.9 in the presence of 1.0 (a), 0.7 (c), 0.4 (b) and 0 (a) $\mathrm{mM} \mathrm{Fe}(\mathrm{III})_{\mathrm{aq}}$. The ageing time is indicated at respective diffractograms, while the y-axis represents intensity.

Fig. 2. Fourier Transform IR spectra of selected transformed products from SHM and SHMAs at $\mathrm{pH} \mathrm{5,6}$ and 6.9 in the presence of $0,0.4,0.7$ and $1.0 \mathrm{mM} \mathrm{Fe}(\mathrm{III})_{\mathrm{aq}}$. The ageing time is shown and the y-axis represents transmission.

Fig. 3. Scanning electron microscopic images of transformed products from unadsorbed As(III) (left) and adsorbed (0.92 wt \%) As(III) (right) schwertmannite after $202 \mathrm{~h}$ in the presence of $0 \mathrm{mM} \mathrm{Fe}(\mathrm{II})_{\mathrm{aq}}$ at $\mathrm{pH} 5$ (top, A \& D), pH 6 (middle, B \& E) and pH 6.9 (bottom, C $\& \mathrm{~F})$.

Fig. 4. Scanning electron microscopic images of transformed products from schwertmannites with unadsorbed As(III) (left) and adsorbed (0.92 wt \%) As(III) (right) after 202h in the presence of $0.4 \mathrm{mM} \mathrm{Fe}(\mathrm{II})_{\mathrm{aq}}$ at $\mathrm{pH} 5$ (top, $\mathrm{A} \& \mathrm{D}$ ), $\mathrm{pH} 6$ (middle, $\mathrm{B} \& \mathrm{E}$ ) and $\mathrm{pH} 6.9$ (bottom, C \& F).

Fig. 5. Scanning electron microscopic images of transformed products from schwertmannites with unadsorbed As(III) (left) and adsorbed (0.92 wt \%) As(III) (right) after 202h in the presence of $0.7 \mathrm{mM} \mathrm{Fe}(\mathrm{II})_{\mathrm{aq}}$ at $\mathrm{pH} 5$ (top, $\mathrm{A} \& \mathrm{D}$ ), $\mathrm{pH} 6$ (middle, $\mathrm{B} \& \mathrm{E}$ ) and pH 6.9 (bottom, C \& F).

Fig. 6. Full Mössbauer spectra obtained at room temperature from original schwertmannite (SHM) and SHM-As and from samples after $202 \mathrm{~h}$ ageing at $\mathrm{pH} 6$ and 6.9, respectively. Open 
circles are the measured data, the solid black line represents the overall fit to the data. Note the hardly visible sextet contribution in the reacted SHM spectra, which are highlighted in a zoomed in version displayed in Figure 4.

Fig. 7. Sulfate desorption kinetic profiles from As(III) loaded (marked as 0.4 mM_As, 0.7 mM_As) and As(III) unloaded schwertmannite (marked as $0.4 \mathrm{mM}, 0.7 \mathrm{mM}$ ) with respect to time in the presence of 0.4 and $0.7 \mathrm{mM} \mathrm{Fe}(\mathrm{II})_{\mathrm{aq}}$ at $\mathrm{pH} 5(\mathrm{~A}), \mathrm{pH} 6(\mathrm{~B})$ and $\mathrm{pH} 6.9(\mathrm{C})$.

Fig. 8. Aqueous residual $\mathrm{Fe}(\mathrm{II})_{\mathrm{aq}}$ variations with respect to time for $\mathrm{As}(\mathrm{III})$ loaded (marked as 0.4 mM_As, 0.7 mM_As) and As(III) unloaded schwertmannite (marked as $0.4 \mathrm{mM}, 0.7 \mathrm{mM}$ ) in the presence of 0.4 and $0.7 \mathrm{mM} \mathrm{Fe}(\mathrm{II})_{\mathrm{aq}}$ at $\mathrm{pH} 5(\mathrm{~A}), \mathrm{pH} 6(\mathrm{~B})$ and $\mathrm{pH} 6.9(\mathrm{C})$.

Fig. 9. Variable fractions of As released during $202 \mathrm{~h}$ ageing from 0.92 wt $\%$ As loaded schwertmannite (SHM-As) in the presence of 0.4 and $0.7 \mathrm{mM} \mathrm{Fe}(\mathrm{II})_{\mathrm{aq}}$ at $\mathrm{pH} 5$ (A), $\mathrm{pH} 6$ (B) and pH $6.9(\mathrm{C})$. 
pH 5

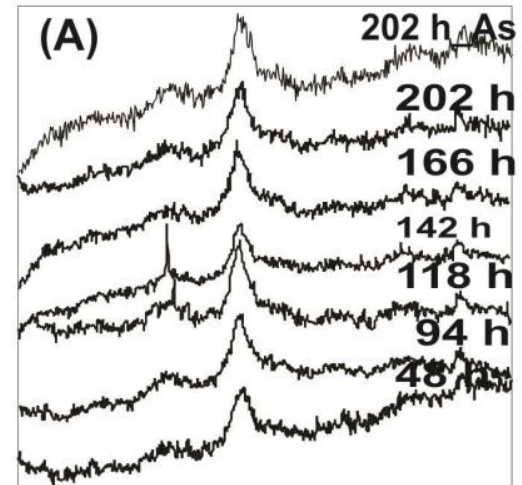

(B)

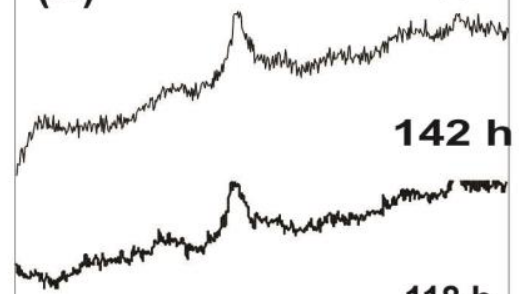

$118 \mathrm{~h}$

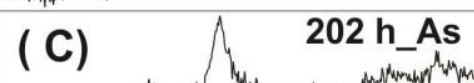

(C)
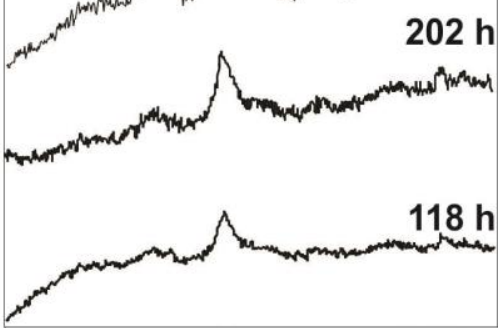

(D) $202 \mathrm{~h}$ (D) Ar $118 \mathrm{~h}$

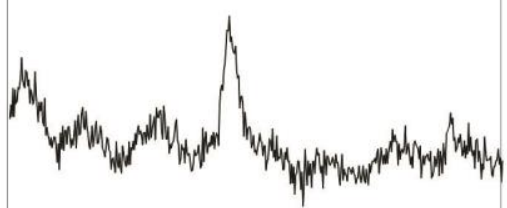
$\begin{array}{lllllll}1.03 & 0.41 & 0.26 & 0.19 & 0.16\end{array}$
pH 6

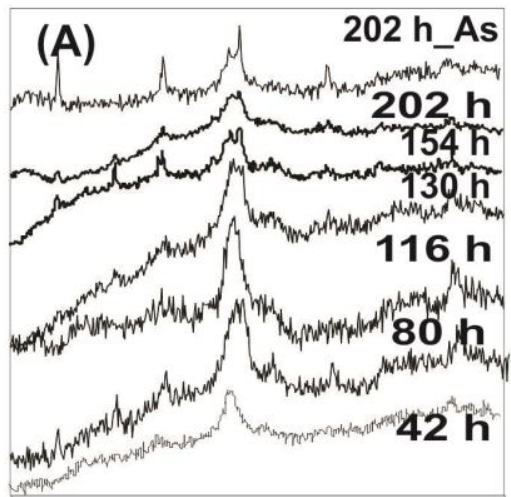

(B) $202 \mathrm{~h} \_$As
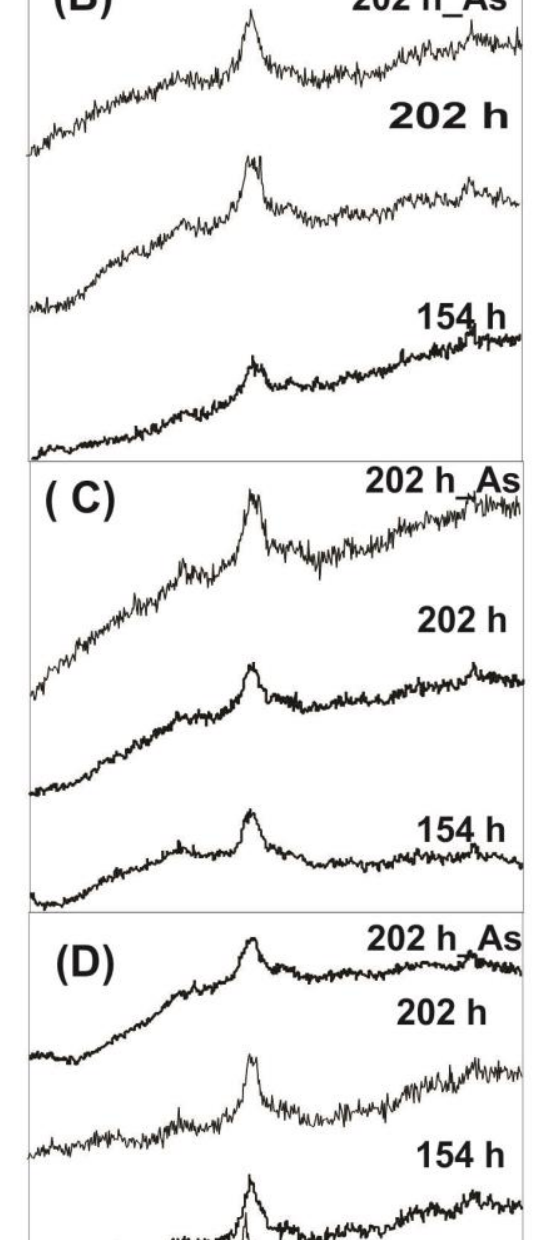

(1)

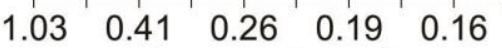
d-spacing $(\mathrm{nm})$
pH 6.9
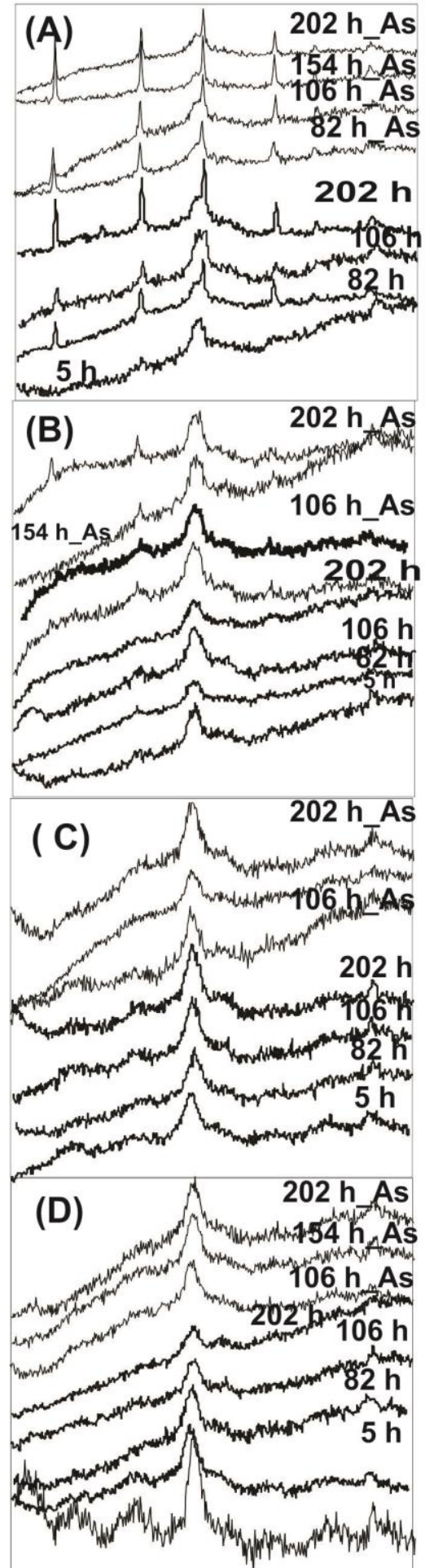

$\begin{array}{lllll}1.03 & 0.41 & 0.26 & 0.19 & 0.16\end{array}$

Fig. 1 
pH 5
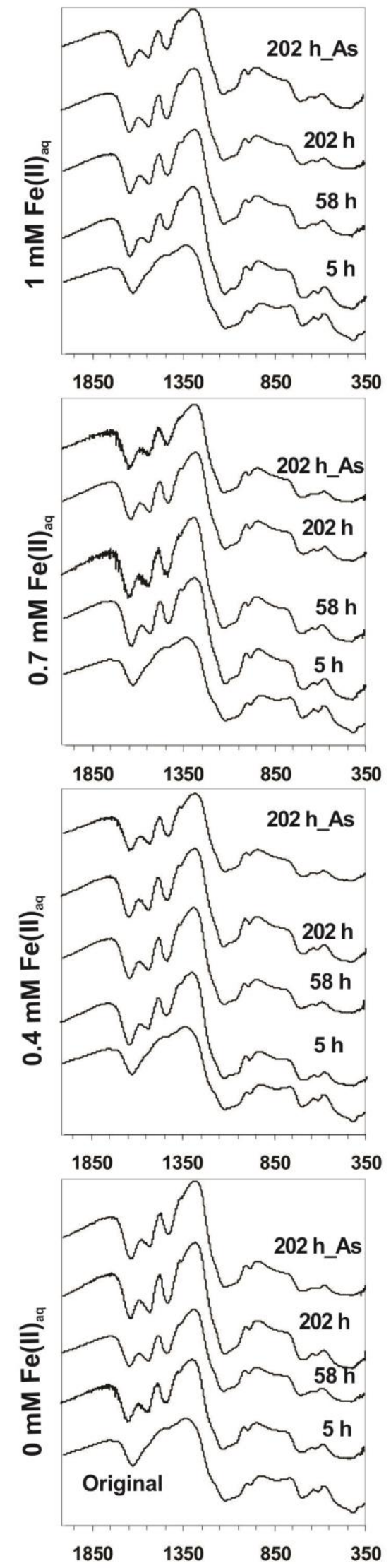

Fig. 2
pH 6
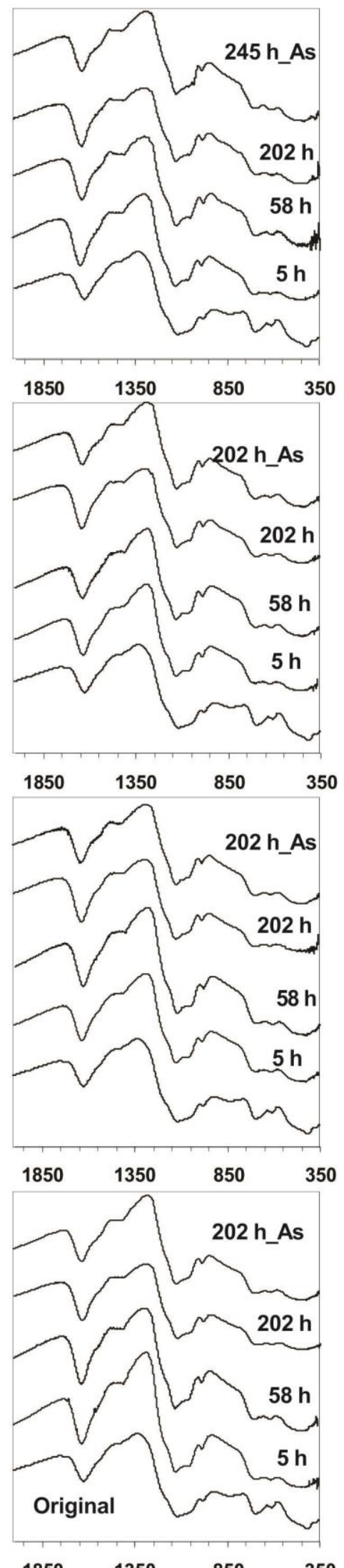

Wavenumber $\left(\mathrm{cm}^{-1}\right)$
pH 6.9
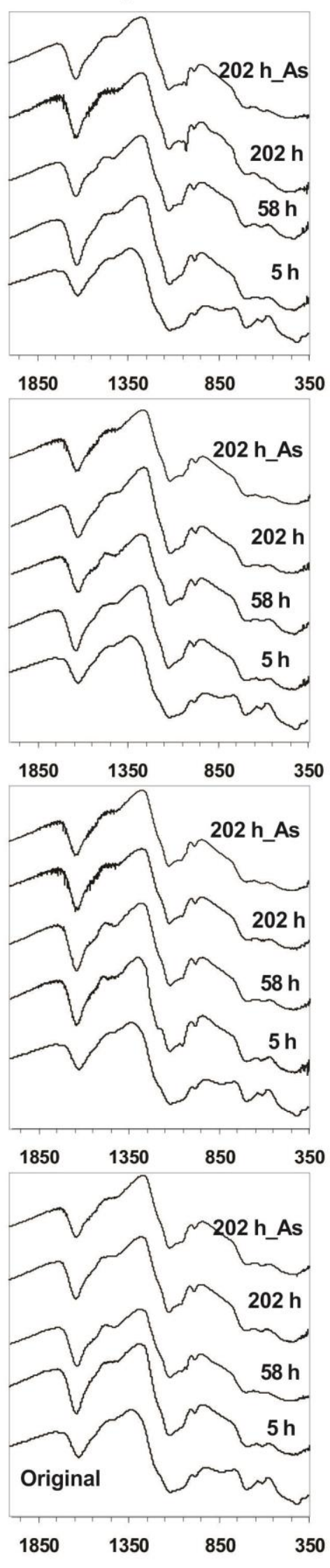

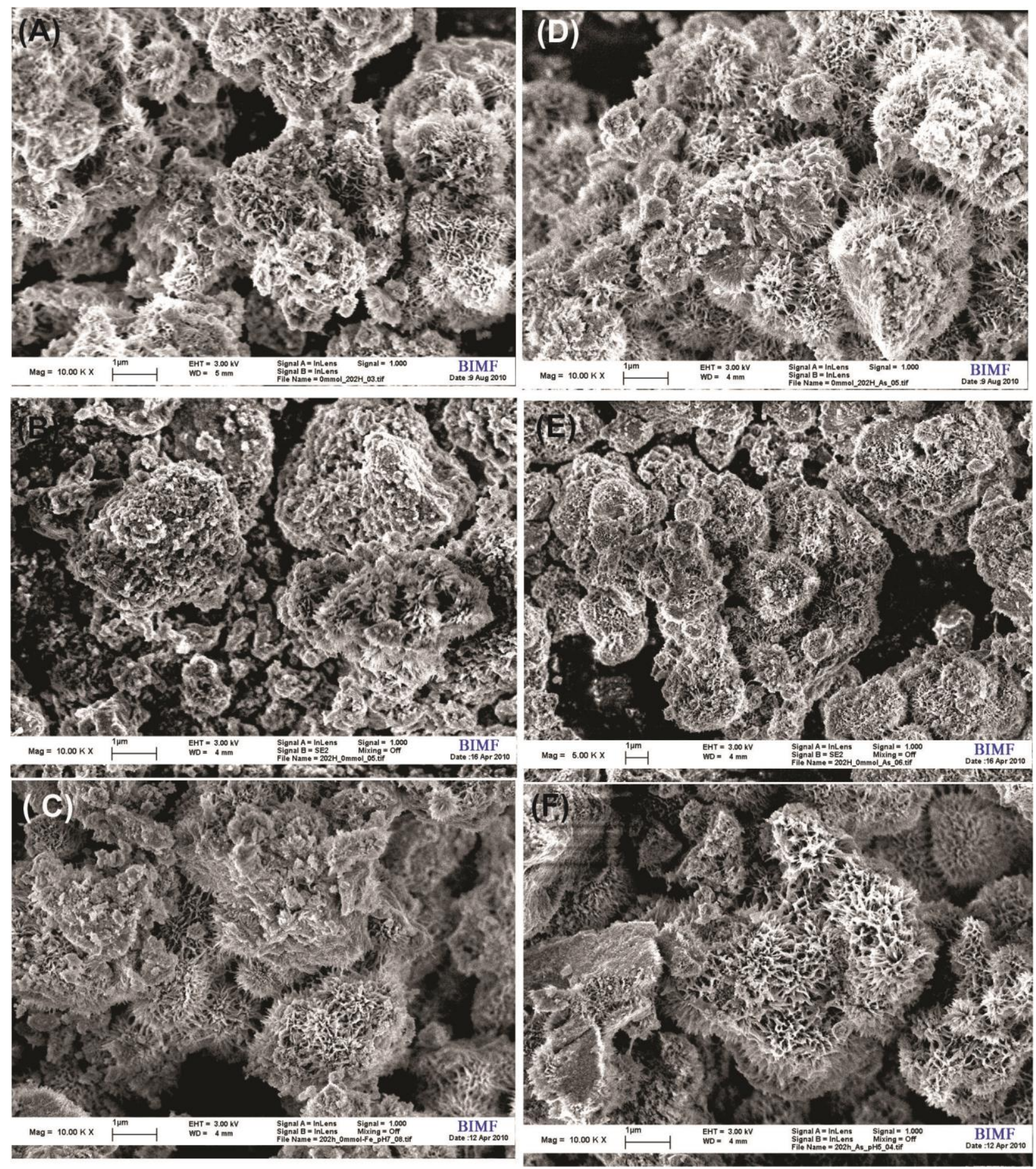

Fig. 3 

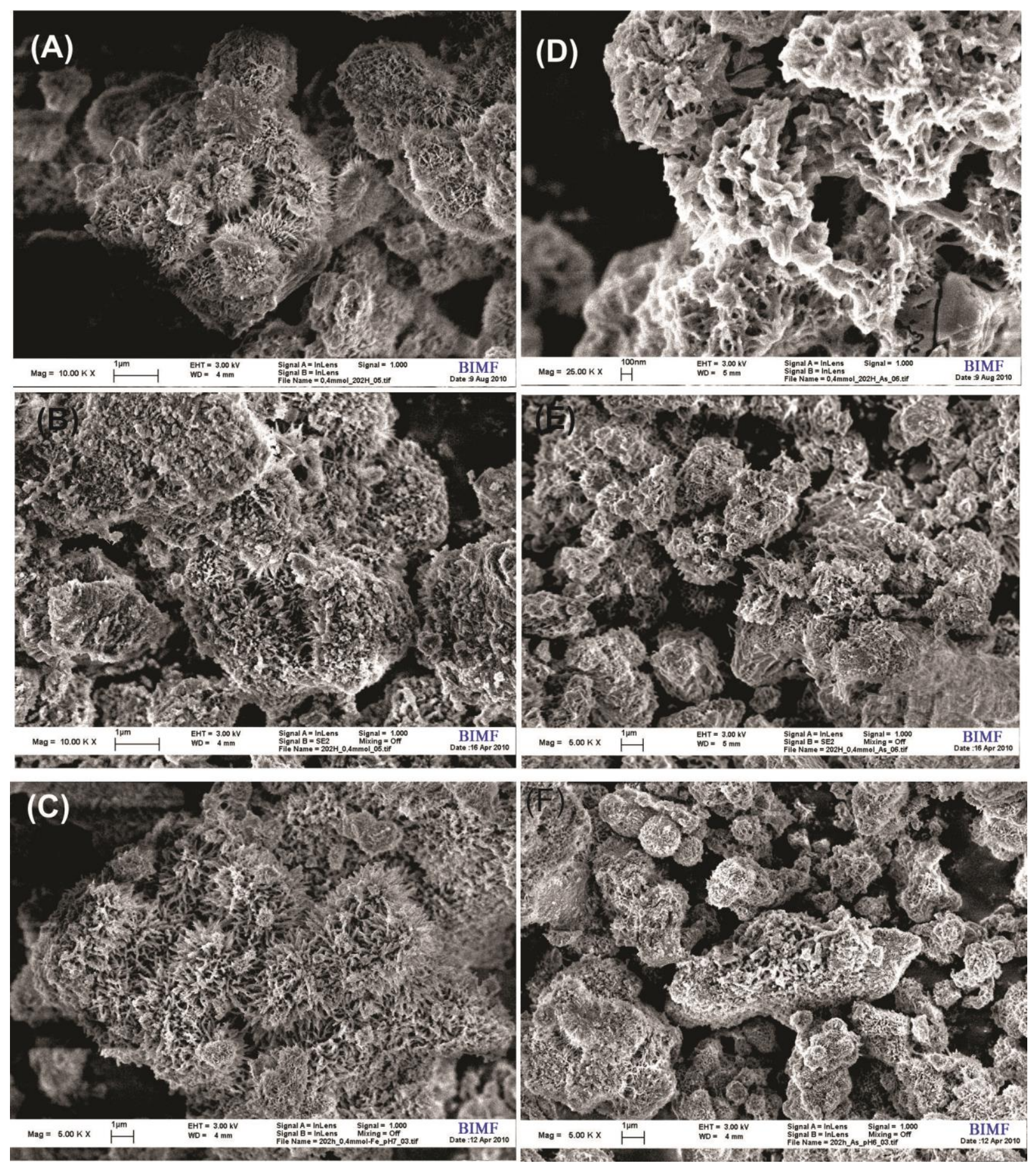

Fig. 4 


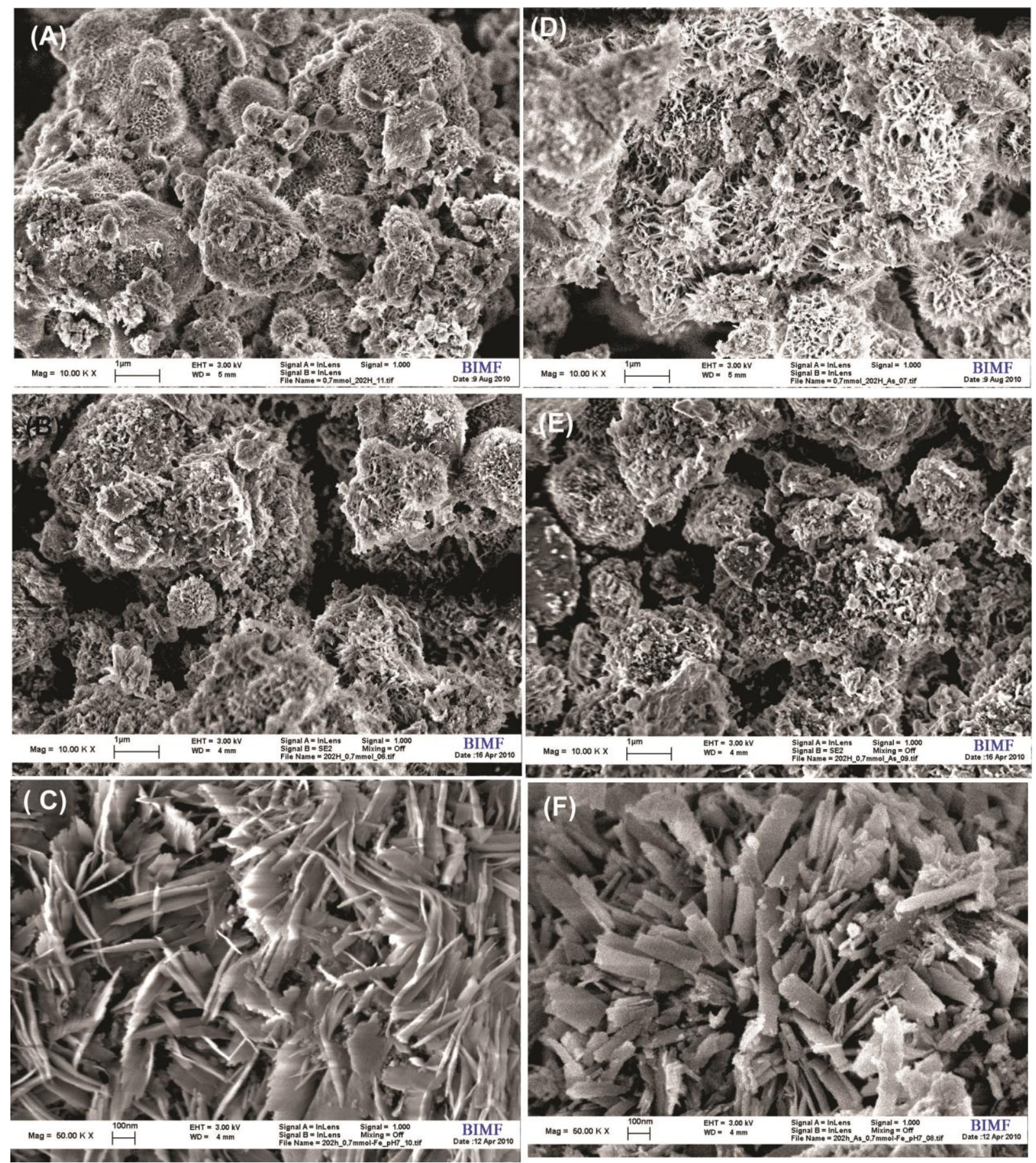

Fig. 5 

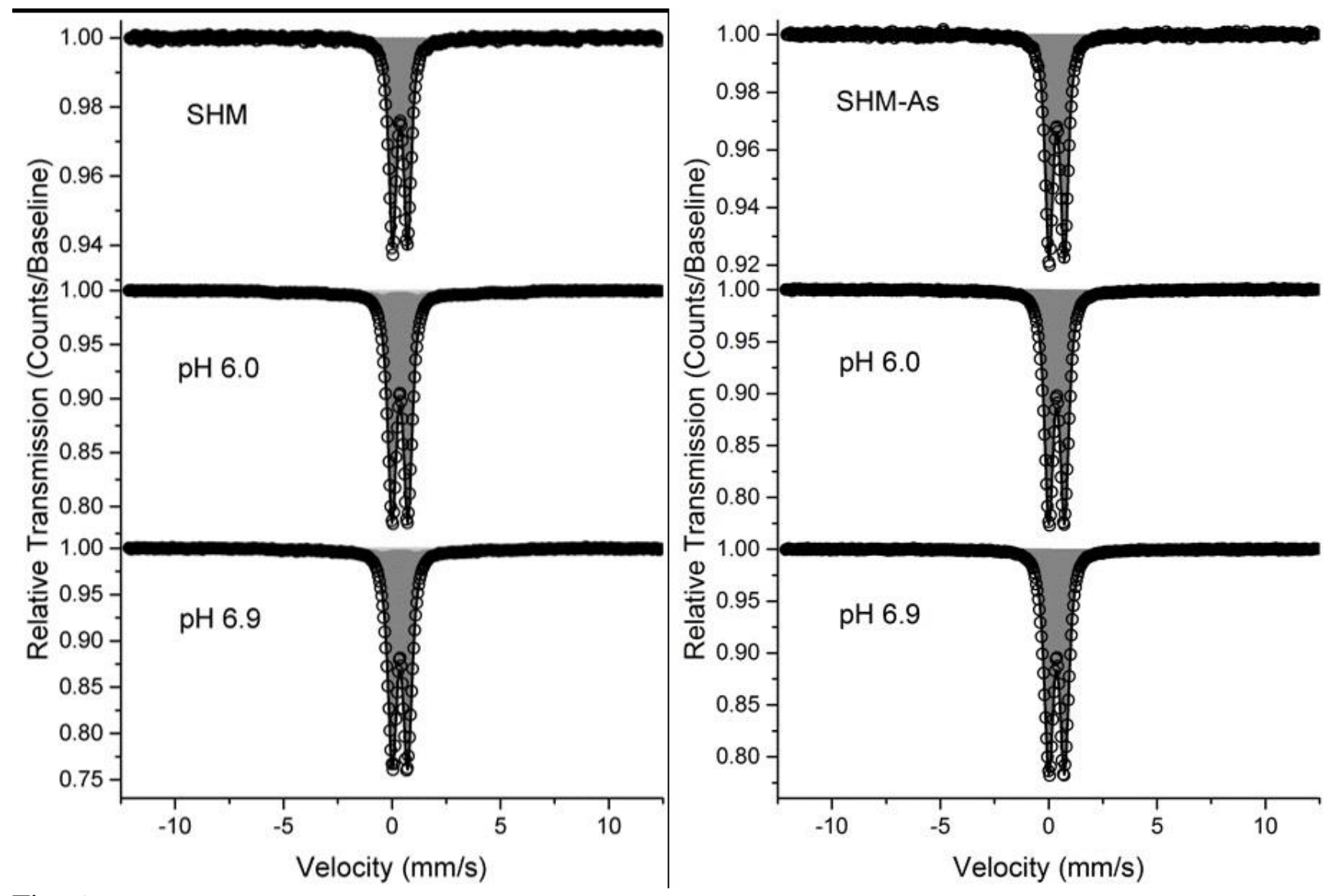

Fig. 6 

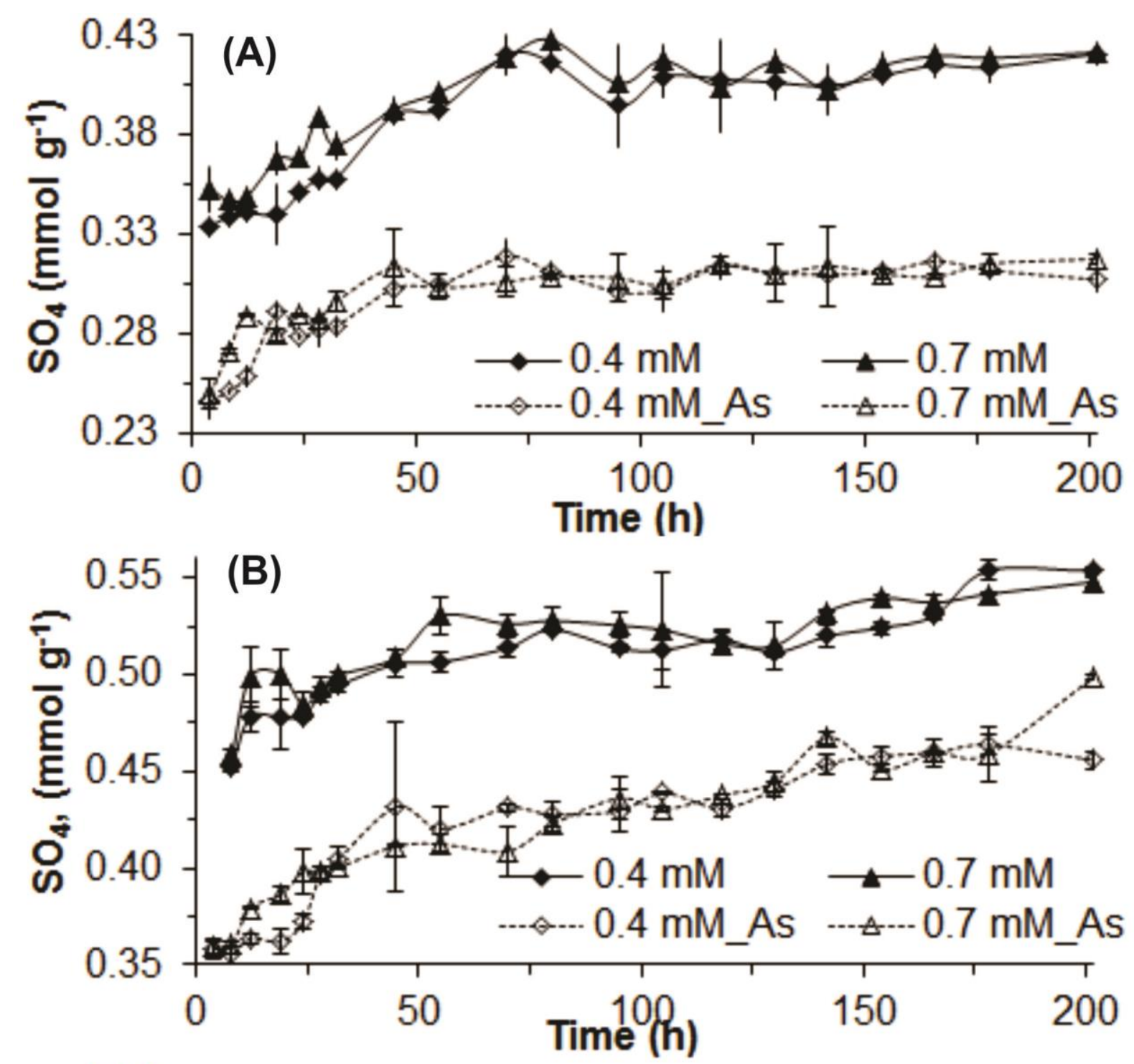

$\begin{array}{ll}1 & \text { Fig. } 7\end{array}$

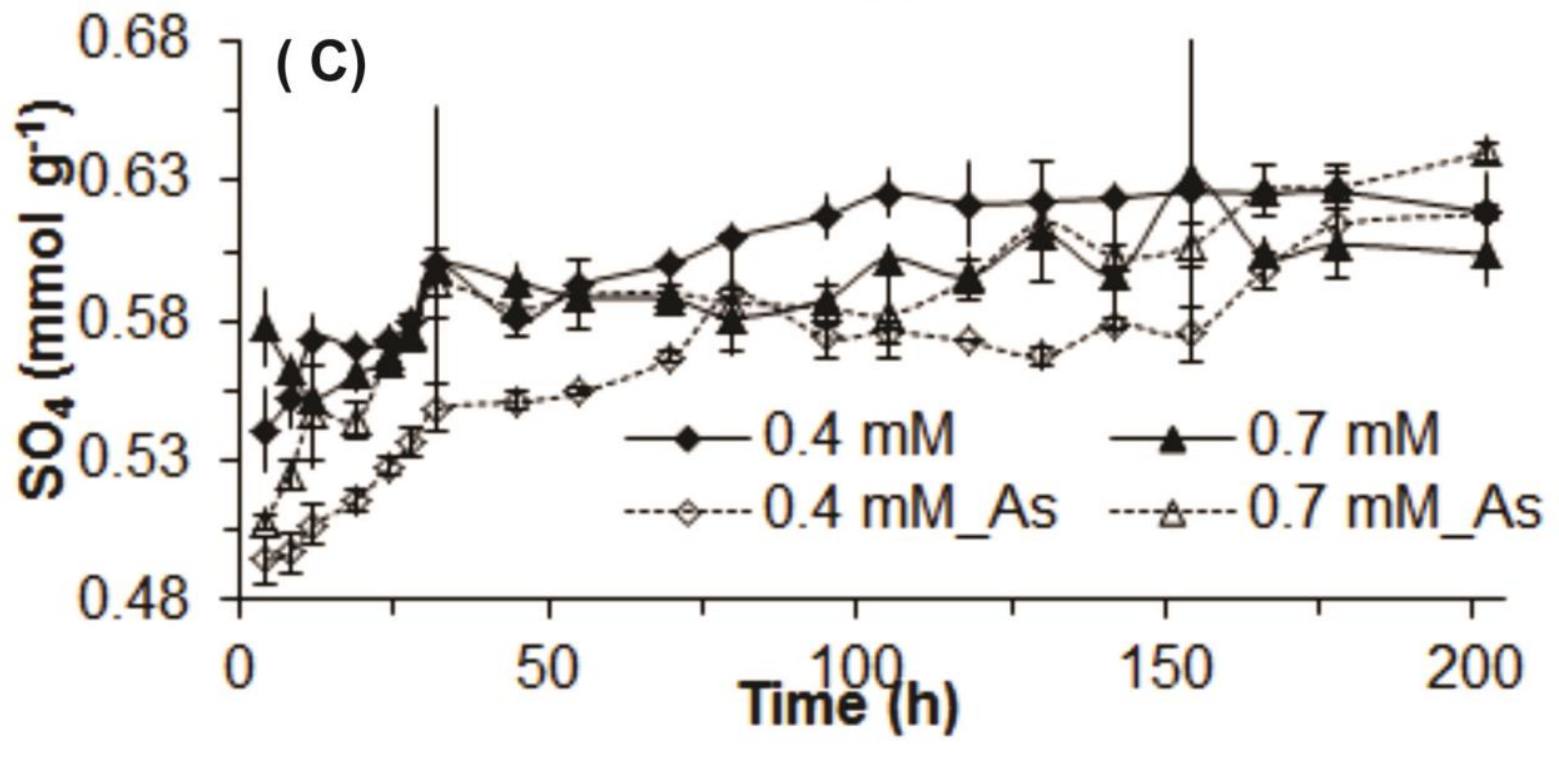



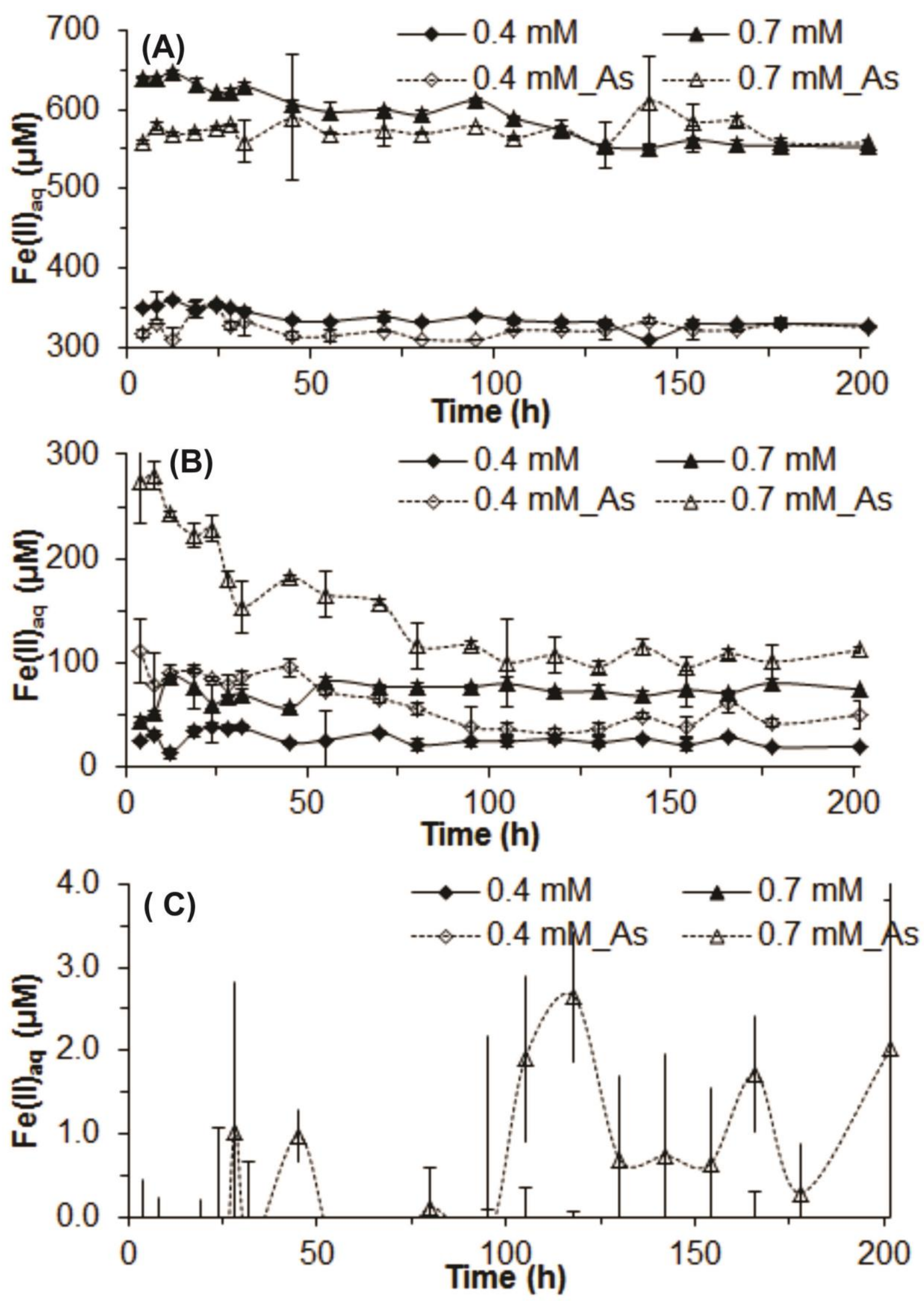

Fig. 8 

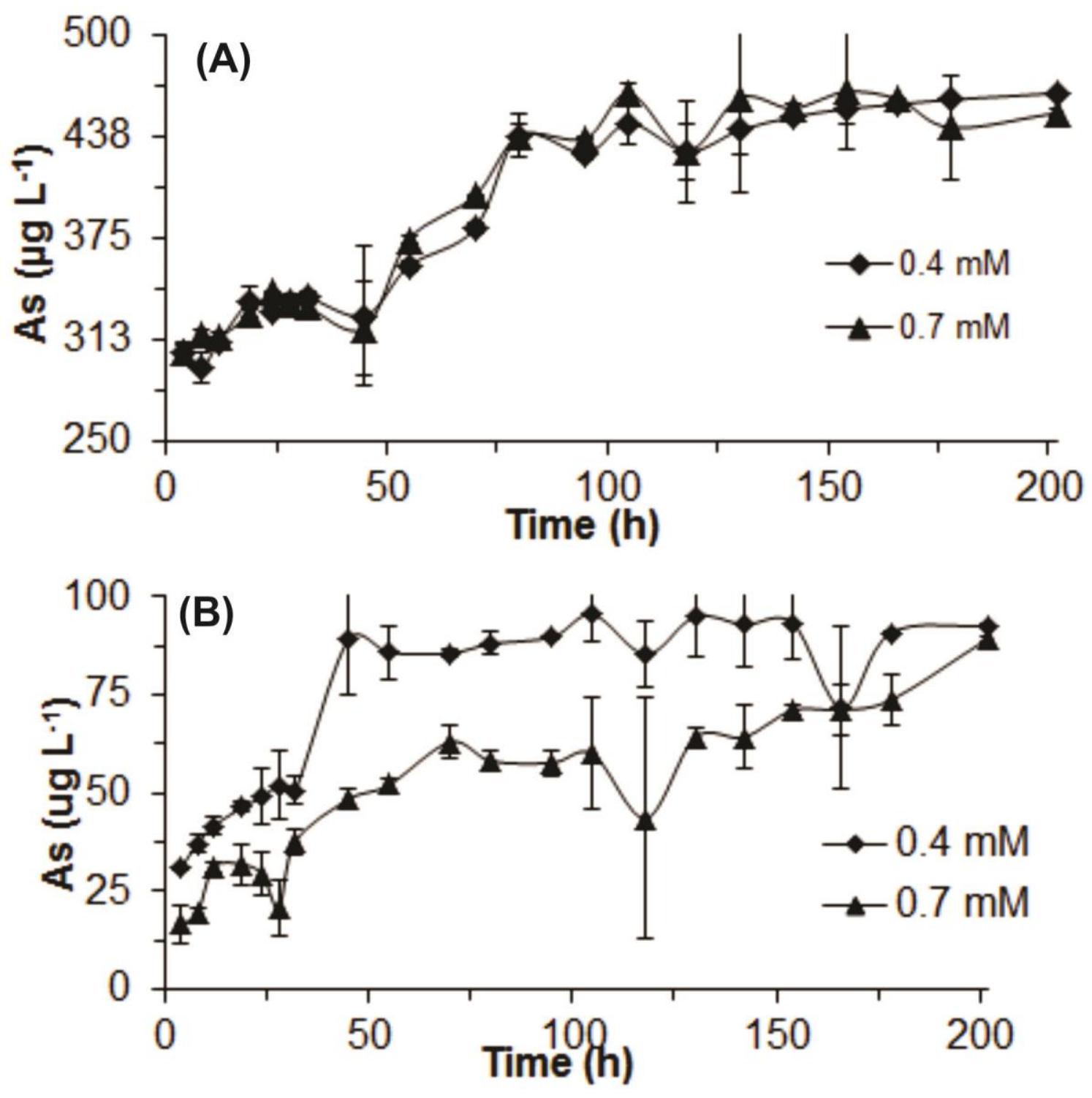

6 Fig. 9

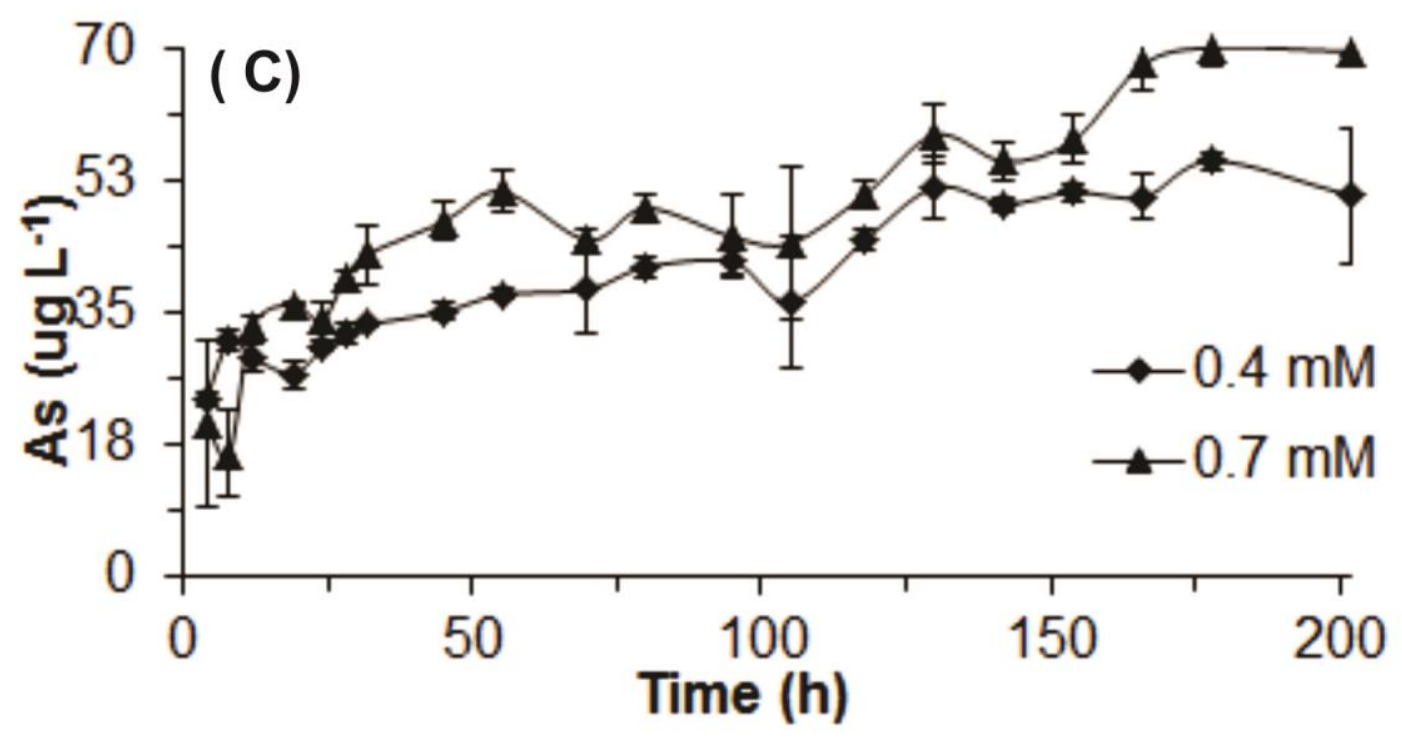



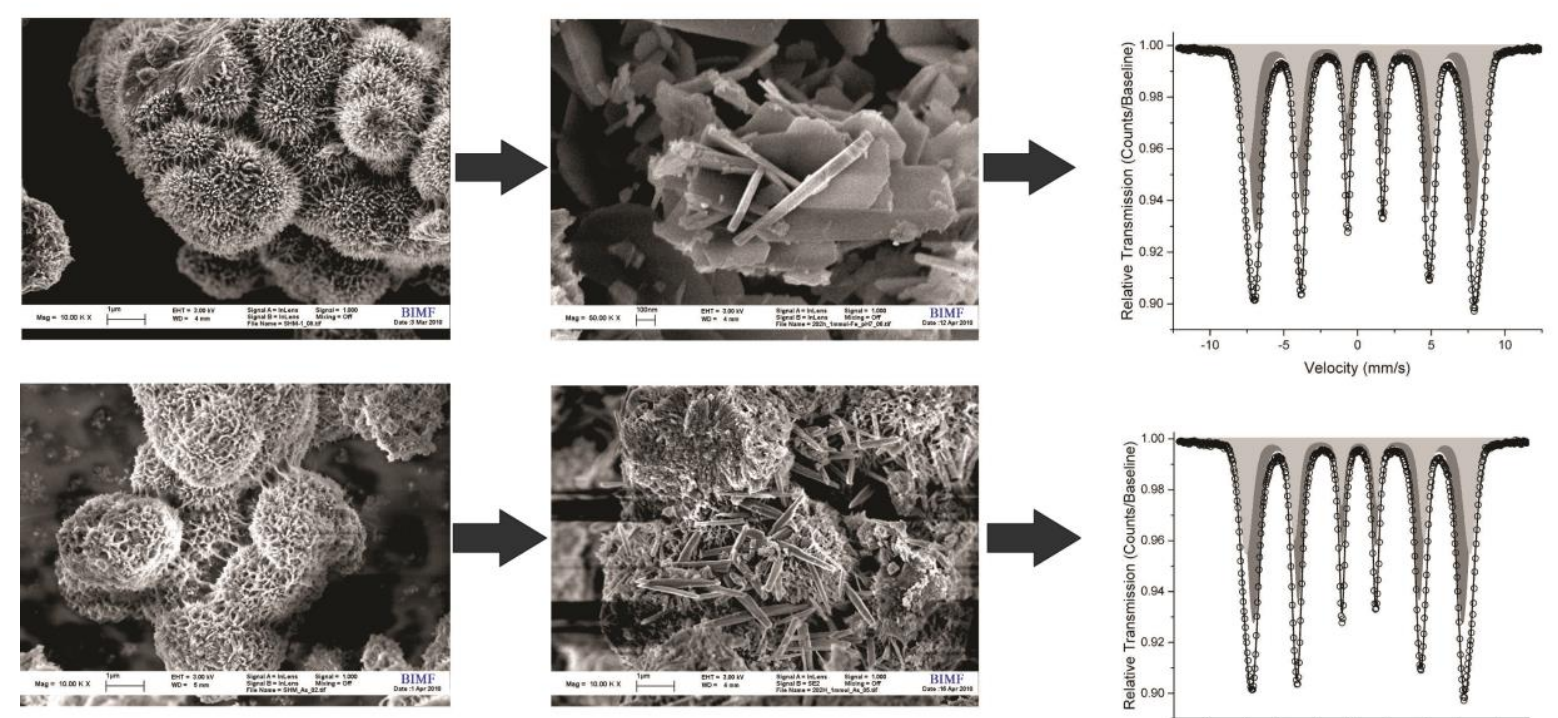

7

8 Graphical abstract 